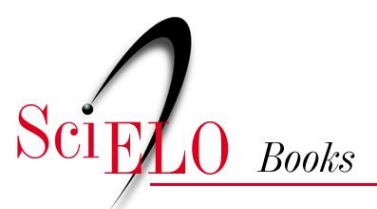

\title{
Violência e saúde
}

\author{
Maria Cecília de Souza Minayo
}

MINAYO, MCS. Violência e saúde [online]. Rio de Janeiro: Editora FIOCRUZ, 2006. Temas em Saúde collection. 132 p. ISBN 978-85-7541-380-7. Available from SciELO Books $<\underline{\text { http://books.scielo.org }>\text {. }}$

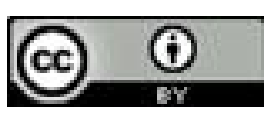

All the contents of this work, except where otherwise noted, is licensed under a Creative Commons Attribution 4.0 International license.

Todo o conteúdo deste trabalho, exceto quando houver ressalva, é publicado sob a licença Creative Commons Atribição $\underline{4.0}$.

Todo el contenido de esta obra, excepto donde se indique lo contrario, está bajo licencia de la licencia Creative Commons Reconocimento 4.0. 
MARIA CECÍLIA DE SOUZA MINAYO

岂

VIOLÊNCIA

E SAÚdE

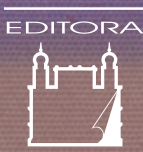

FIOCRUZ 
Violência e Saúde 
FUNDAÇÃO OSWALDO CRUZ

Presidente

Paulo Ernani Gadelha Vieira

Vice-Presidente de Ensino, Informação e Comunicação

Maria do Carmo Leal

\section{EDITORA FIOCRUZ}

Diretora

Maria do Carmo Leal

Editor Executivo

João Carlos Canossa Mendes

Editores Científicos

Nísia Trindade Lima

Ricardo Ventura Santos

Conselho Editorial

Ana Lúcia Teles Rabello

Armando de Oliveira Schubach

Carlos E. A. Coimbra Jr.

Gerson Oliveira Penna

Gilberto Hochman

Joseli Lannes Vieira

Ligia Vieira da Silva

Maria Cecilia de Souza Minayo

Coleção Temas em Saúde

Editores Responsáveis

Maria do Carmo Leal

Nísia Trindade Lima

Ricardo Ventura Santos 
MARIA CECÍLIA DE SOUZA MINAYO

\section{Violência e Saúde}

$1^{\text {a }}$ Reimpressão

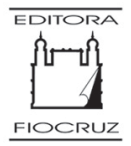


Copyright (C) 2006 da autora

Todos os direitos desta edição reservados à

FUNDAÇÃO OSWALDO CRUZ / EDITORA

ISBN: 85-7541-071-7

$1^{\mathrm{a}}$ Edição: 2005

$1^{\text {a }}$ Reimpressão: 2010

Capa, projeto gráfico e editoração eletrônica

Carlota Rios

Revisão

Fernando Arosa

Supervisão Editorial

M. Cecilia G. B. Moreira

Catalogação na fonte

Centro de Informação Científica e Tecnológica

Biblioteca da Escola Nacional de Saúde Pública Sergio Arouca

M663v Minayo, Maria Cecília de Souza

Violência e Saúde. Maria Cecília de Souza

Minayo. Rio de Janeiro : Editora FIOCRUZ, 2006.

132 p. (Coleção Temas em Saúde)

1.Violência. 2. Saúde pública I.Título.

CDD - 20.ed. - 362.1

2010

EDITORA FIOCRUZ

Av. Brasil, 4036 - Térreo - sala 112 - Manguinhos

21040-361 - Rio de Janeiro - RJ

Tels: (21) 3882-9039 / 3882-9041

Telefax: (21) 3882-9006

e-mail: editora@fiocruz.br

http://www.fiocruz.br 


\section{SUMÁrio}

Apresentação

Parte I - Violência como Processo Sócio-histórico

1. Um Fenômeno de Causalidade Complexa

2. O Contexto da Violência Social no Brasil

3. Um Olhar sobre a Violência Social Brasileira

4. Prejuízos, Lucros e Interesses

Parte II - Violência e Saúde Pública

5. Violências e Acidentes na Pauta do Setor Saúde

6. Iniciativas do Setor Saúde

7. Morbi-mortalidade por Violências e Acidentes

8. Quadro Interpretativo da Violência sob a ótica do Setor Saúde

9. Expressões Culturais de Violência e Relação com a Saúde 
Parte III - Modos de Atuação: Pesquisa e intervenção

10. Abordagens da Magnitude e dos Sentidos da Violência

11. Elementos para Atuação do Setor Saúde

Referências

Sugestões de Leituras 


\section{Apresentação}

Neste livro busco introduzir uma reflexão sobre as articulações entre o tema da violência e suas repercussões na saúde dos brasileiros. Trabalho em três vertentes: a primeira, no campo sociológico de conceituação da violência; a segunda, na articulação entre violência e saúde; a terceira nas propostas de atuação. Por mais que tentasse, não foi possível oferecer ao leitor uma visão muito simplificada da questão, uma vez que o tema é complexo, polissêmico e controverso. Busquei, então, um texto claro e fácil de ser compreendido por qualquer pessoa que, como eu, tem perguntas e busca respostas para este fenômeno. Confesso que, depois de mais 17 anos pesquisando e estudando, continuo sem entender muitos de seus aspectos e tenho mais dúvidas que certezas sobre as manifestações da violência. Portanto, advirto a quem me acompanhar nesta leitura, que minha exposição contém idéias, conceitos, classificações e interpretações passíveis de serem refutadas por outros estudiosos, sem que nem eu nem eles tenhamos condições de nos colocar como portadores da verdade sobre o tema.

Para realizar este trabalho, iniciei com uma discussão mais ampla que abrange aspectos históricos, culturais, sociológicos e até econômicos, uma vez que, em suas relações, a violência se apresenta ora como manifestação da dinâmica e da trajetória de 
uma sociedade - seja em seus aspectos estruturais ou conjunturais -, ora como fenômeno específico que se destaca e influencia essa mesma dinâmica social. Parafraseando Pascal, diria que a violência é uma manifestação causada por outros processos e também causadora desses processos. Ou como diria Hannah Arendt, "a violência dramatiza causas" e possibilita à sociedade a compreensão de seus próprios limites.

Como fenômeno sócio-histórico, a violência acompanha toda a experiência da humanidade. Sua presença está registrada em vários documentos da Antiguidade e é lembrada no mito de origem contido na narrativa bíblica em forma de disputa fratricida. Os ressentimentos de Caim contra seus pais e a morte de Abel, seu irmão, pensada e perpetrada por ele, evidenciam a convivência da sociedade humana com perenes disputas de poder, com ódios e com a vontade de aniquilar uns aos outros. Essa vontade de aniquilamento, no decurso da história e das culturas, se manifesta de várias formas como: desprezo e menosprezo pelo outro, discriminações, crueldades, autoritarismo, lutas fratricidas, guerras, terrorismos e processos de autodestruição.

A violência, em si, não é um tema da área de saúde, mas a afeta porque acarreta lesões, traumas e mortes físicas e emocionais. Para compreender o impacto da violência sobre a saúde, devemos localizar a sua discussão no conjunto dos problemas que relacionam saúde, condições, situações e estilo de vida. $\mathrm{Na}$ maioria dos países desenvolvidos há mais tempo, e no Brasil, nos últimos trinta anos, as enfermidades infecciosas vêm cedendo lugar às doenças crônicas e degenerativas e aos agravos que dependem, em grande parte, das condições de vida, das questões ambientais, dos avanços da ciência e tecnologia do setor, 
sobretudo na área da biologia e também, mas não prioritariamente, das intervenções e procedimentos médicos.

A esse movimento de mudança no perfil e no contexto das taxas de mortalidade e de morbidade, os estudiosos dão o nome de 'transição epidemiológica'. No caso brasileiro, a transição epidemiológica é sui generis, pois, nosso quadro de morbidade (principalmente) e de mortalidade combina enfermidades e agravos típicos dos países desenvolvidos com situações próprias de nações subdesenvolvidas. Isso ocorre, dentre outros motivos, por causa das imensas diferenciações e desigualdades entre grupos sociais (por exemplo, étnicos, raciais, de gênero etc.).

Este livro constitui uma síntese de minha experiência: há 17 anos estou pesquisando o impacto da violência sobre a saúde, junto com um grupo de pesquisa que a Fundação Oswaldo Cruz (Fiocruz) criou na administração do saudoso Sergio Arouca. Este grupo que se instituiu na Escola Nacional de Saúde Pública (Ensp), com a denominação de Centro Latino-Americano de Estudos sobre Violência e Saúde (Claves), desde o início teve uma orientação multidepartamental e interdisciplinar, tendo em vista que é praticamente impossível estudar a violência apenas com um foco disciplinar e de forma compartimentalizada. Atualmente, o Centro congrega pesquisadores de outras unidades da Fiocruz, como é o caso do Instituto Fernandes Figueira (IFF), tem o apoio do Centro de Informações para a Ciência e a Tecnologia em Saúde (Cict), atua em colaboração com a Bireme no projeto de Biblioteca Virtual sobre Violência e Saúde, tem pesquisas cooperativas nacionais e internacionais e é Centro Colaborador do Ministério da Saúde/Secretaria de Vigilância em Saúde (MS/SVS). 
O Claves, do qual desde a origem sou a coordenadora científica, é um dos exemplos das iniciativas acadêmicas hoje existentes no país. Tem a vantagem de se constituir como equipe institucionalizada, o que garante a sua continuidade. $\mathrm{O}$ incremento da violência na realidade brasileira vem repercutindo intensamente no pensamento intelectual do país, sobretudo a partir da década de 1990. Estudos bibliográficos realizados por nós mostram que $95 \%$ da produção acadêmica sobre o tema ocorreram depois de 1980.

O tema, no âmbito da reflexão em saúde pública, tem história, nomes e tradições que vêm desde os anos 70, concentrandose primeiramente na Faculdade de Saúde Pública de São Paulo (FSP/USP) e na Universidade Estadual de Campinas (Unicamp). A Fiocruz, até a criação do Claves, colaborava com poucos estudos, e os existentes tinham apenas um cunho epidemiológico descritivo e eram realizados com dados secundários. O fato de o Claves estar exclusivamente voltado para pesquisar este assunto dinamizou a produção institucional e foram abertos vários campos de pesquisa empírica, tornando-o o mais produtivo do país.

Em que pesem os esforços dos pesquisadores e das instituições, a reflexão brasileira a respeito da violência social e do impacto da violência na saúde dos brasileiros é ainda incipiente. Os estudos se restringem quase sempre a diagnósticos de situações pontuais, e apenas nos últimos dez anos os resultados das investigações vêm sendo apropriados pelos serviços de saúde. 


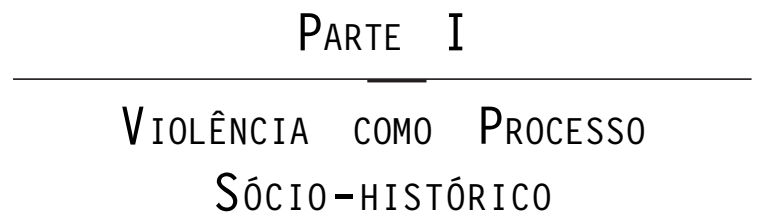





\section{1 , Um Fenômeno de Causalidade Complexa}

A violência não é uma, é múltipla. De origem latina, o vocábulo vem da palavra vis, que quer dizer força e se refere às noções de constrangimento e de uso da superioridade física sobre o outro. No seu sentido material, o termo parece neutro, mas quem analisa os eventos violentos descobre que eles se referem a conflitos de autoridade, a lutas pelo poder e a vontade de domínio, de posse e de aniquilamento do outro ou de seus bens. Suas manifestações são aprovadas ou desaprovadas, lícitas ou ilícitas segundo normas sociais mantidas por usos e costumes ou por aparatos legais da sociedade. Mutante, a violência designa, pois - de acordo com épocas, locais e circunstâncias - realidades muito diferentes. Há violências toleradas e há violências condenadas. Introduzindo sua obra clássica sobre duzentos anos de história da violência na Europa, adverte Chesnais (1981: 11):

o leitor deste livro terá a impressão de entrar num universo fragmentado, disparatado e sem grande unidade. Mas, a própria violência é que se apresenta como um fenômeno pulverizado, atingindo a vida privada e a vida pública em todos os seus aspectos, os mais visíveis e os mais secretos.

Encerrar a noção de violência numa definição fixa e simples é expor-se a reduzi-la, a compreender mal sua evolução e sua especificidade histórica. Ao Introduzir os registros de um seminário da Unesco sobre o mesmo tema lembra o filósofo Domenach (1981: 40): 
Suas formas mais atrozes e mais condenáveis geralmente ocultam outras situações menos escandalosas, por se encontrarem prolongadas no tempo e protegidas por ideologias ou instituições de aparência respeitável. A violência de indivíduos e grupos tem que ser correlacionada com a do Estado. A dos conflitos, com a da ordem.

A maior parte das dificuldades para conceituar a violência vem do fato de ela ser um fenômeno da ordem do vivido, cujas manifestações provocam ou são provocadas por uma forte carga emocional de quem a comete, de quem a sofre e de quem a presencia. Por isso, para entender sua dinâmica na realidade brasileira vale a pena fazer uma pausa para compreender a visão que a sociedade projeta sobre o tema, seja por meio da filosofia popular, seja ponto de vista erudito. Os eventos violentos sempre passaram e passam pelo julgamento moral da sociedade.

\section{VISÃO POPULAR: VIOLÊNCIA COMO CRIME, CORRUPÇÃO E PECADO}

A violência dominante na consciência contemporânea é a 'criminal' e 'delinqüencial'. Esse tipo de fenômeno nunca teve a tolerância social, uma vez que ele fere, antes de tudo, a moral fundamental de todas as culturas. Colocando o termo no plural, Chesnais (1981) distingue no imaginário social atual, três definições de violências que contemplam tanto o âmbito individual quanto o coletivo: no centro de tudo, a 'violência física', que atinge diretamente a integridade corporal e que pode ser traduzida nos homicídios, agressões, violações, torturas, roubos a mão armada; a 'violência econômica', que consiste no desrespeito e apropriação, contra a vontade dos donos ou de 
forma agressiva, de algo de sua propriedade e de seus bens; e, por último, a 'violência moral e simbólica', aquela que trata da dominação cultural, ofendendo a dignidade e desrespeitando os direitos do outro.

Interpretando uma pesquisa de opinião realizada com a população carioca, pela Rede Globo de Televisão, Luiz Eduardo Soares e Leandro Piquet Carneiro (1996) encontraram nos critérios populares quatro nomes para a violência: crime, pecado, corrupção e miséria. Pecado é o nome da violência interpretada pelo código religioso, expressando a natureza ambivalente ou passível de perversão da própria condição humana. Corrupção é o nome da violência que contém a moralidade deteriorada e a traição dos valores. Miséria é o nome da violência, lida pela ótica política, que a enxerga embutida nas causas e conseqüências da ordem social vigente, marcada pela desigualdade e pela exclusão. Crime é o nome da violência reduzida à delinqüência.

Em ambos os estudos, as relevâncias são dadas para o sentido moral, econômico e criminoso dos atos violentos e seu atentado à vida e à integridade social e pessoal. Poderíamos nos perguntar: existe algo mais constante na história humana que os fenômenos classificados (e a forma de classificá-los) pela sabedoria popular carioca? Se existe esta permanência cultural tão forte no sentido dado à violência social pelo povo, no inconsciente popular se localiza também a certeza de que a violência é parte intrínseca da vida social e resultante das relações, da comunicação e dos conflitos de poder. Nunca existiu uma sociedade sem violência, mas sempre existiram sociedades mais violentas que outras, cada uma com sua história. 


\section{VISÃO ERUDITA: VIOLÊNCIA COMO NEGAÇÃO DE DIREITOS DO 'OUTRO' E INSTRUMENTO DE PODER}

Filósofos e cientistas também têm contribuído para discutir o tema da violência. Domenach, um dos grandes pensadores sobre o assunto, sublinha a idéia de que a violência está inscrita e arraigada nas relações sociais, mas, principalmente, que é construída no interior das consciências e das subjetividades. Portanto, esse fenômeno não pode ser tratado apenas como uma força exterior aos indivíduos e aos grupos. Sua visão se projeta na direção contrária ao senso comum que costuma colocá-la como um fenômeno sempre produzido pelo 'outro': “É demasiado fácil e ineficaz condenar a violência como um fenômeno exterior, e inclusive, como algo estranho ao ser humano, quando, na verdade ela o acompanha, incessantemente, até na articulação de seu discurso e na afirmação mesma da evidência racional" (Domenach, 1981: 37).

Falando das dificuldades de definições e dos julgamentos de valor que sempre existem quando tratamos desse tema, Domenach (1981: 38) continua: “estou convencido de que é inútil buscar uma resposta categórica na filosofia ou na moral, ao problema que a violência levanta. Por seu aspecto ontológico, ela não pode ser dissociada da condição humana". O autor reforça ainda a idéia de que a violência não pode ser analisada nem tratada fora da sociedade que a produz em sua especificidade interna e em sua particularidade histórica.

Domenach (1981) e Chesnais (1981) defendem que a percepção negativa e condenatória das várias formas de violência constitui um passo muito positivo alcançado pela humanidade em seu desenvolvimento. Ou seja, atribuir a um ato de explora- 
ção, de dominação, de agressão física, emocional ou moral o caráter negativo de violência significa um status superior da consciência social a respeito dos direitos dos indivíduos e de coletividades. Tal compreensão acompanha o progresso do espírito democrático. Pois é a partir do momento em que cada pessoa se considera e é considerada 'cidadã' que a sociedade reconhece seu direito à liberdade e à felicidade e que a violência passa a ser um fenômeno relacionado ao emprego ilegítimo da força física, moral ou política, contra a vontade do outro.

A associação da percepção da violência como um fenômeno negativo à maior consciência de liberdade e aos direitos humanos, no caso brasileiro, contra qualquer evidência empírica, é um fato positivo. Isso pode significar, a par da consciência da intensificação das manifestações do fenômeno (o que é real), o crescimento e a ampliação da democracia e dos processos de reconhecimento social. Exatamente, o final da década de 1970 e o início da década seguinte coincidem, ao mesmo tempo, com a consciência nacional sobre o acirramento da violência social e com os processos de abertura democrática no país. A partir de então, crescem os movimentos em prol dos direitos civis e sociais e da emancipação da mulher, da criança, dos negros e de outros grupos excluídos.

Do ponto de vista filosófico e sociológico costumam circular pelo menos três fontes explicativas para a violência. Uma delas a considera como expressão de crises sociais que levam a população mais atingida negativamente, à revolta frente à sociedade ou ao Estado que não conseguem lhe dar respostas adequadas. Tais teorias que dominaram o pensamento das décadas de 1960 e 1970 têm amparo em Toquecville, que explica a violência do povo na Revolução Francesa como reação a uma situ- 
ação insuportável, ou em outros autores como Fanon, que a justifica como vingança dos pobres e explorados; em Sorel que a define como o mito necessário para a transformação da sociedade burguesa desigual numa sociedade igualitária de base popular; e em Sartre, que a considera como um fenômeno inevitável no universo da escassez e das necessidades sociais. Tais interpretações também vão ao encontro das teorias denominadas de 'frustração relativa' que se apóiam na idéia de que a violência nasce da distância entre expectativas de determinados grupos e a impossibilidade que a sociedade tem de satisfazê-las.

Um segundo grupo de teóricos insiste no caráter racional e instrumental da violência, que constituiria um meio para atingir fins específicos. Esse grupo tenta explicar como atores excluídos do campo político utilizam a violência para conseguir se manter no palco do poder. Diferentemente das primeiras que colocam os atores como 'vítimas' ou 'deserdados', esses teóricos consideram a pessoa violenta como um ser consciente que atua no campo de interações. Tais estudiosos não separam a violência da análise dos conflitos gerais da sociedade. Engels (1981), por exemplo, valoriza a violência como um acelerador do desenvolvimento econômico. E Hannah Arendt a considera como um meio e um instrumento para a conquista do poder. Essa autora, no entanto, não confunde poder e violência. Pelo contrário, ressalta que só existe violência quando há incapacidade de argumentação e de convencimento. Arendt (1990) não vê positividade na violência e expressa seus argumentos, de forma contundente, na obra em que analisa o nazismo e o estalinismo, evidenciando os tipos de crueldade que se materializaram nas experiências políticas totalitárias. Por isso, na construção de sua argumentação, Arendt (1994) reage aos autores que promovem 
uma visão de que se poderia justificar a violência, desde que estivesse a serviço de uma transformação social ou individual potencialmente mais perfeita.

Um terceiro grupo de estudiosos ressalta a forte articulação entre violência e cultura, sobretudo apoiados na obra do filosofo, historiador e cientista social Norbert Elias (1993). Esse autor mostra o papel civilizatório da modernidade que criou mecanismos de institucionalização e de solução de conflitos, levando os indivíduos a dominarem sua agressividade e suas pulsões violentas. Também Freud (1980) apresenta várias interpretações da violência no mesmo sentido, em diferentes etapas de seu pensamento. Em seus primeiros escritos, esse pensador a associa à agressividade instintiva do ser humano, o que o inclinaria a fazer sofrer e a matar seu semelhante. Num segundo momento, define-a como instrumento para arbitrar conflitos de interesse, sendo, portanto, um princípio geral da ação humana frente a situações competitivas. Numa terceira etapa, avança para a idéia de construção de identidade de interesses. É dessa identidade, segundo o autor, que surgem os vínculos emocionais entre os membros da comunidade humana, levando-os a preferirem a civilização, o diálogo e a convivência pacífica, ao uso puro e simples da força física para se imporem. Em síntese, na visão desses autores, os conflitos de interesse nas sociedades modernas passaram a ser mediados pelo direito e pela lei; e a comunidade de interesses, pela identidade e pela busca do bem coletivo. Um dos problemas da abordagem culturalista é que ela não inclui as mediações políticas, sociais e subjetivas.

Em recente trabalho, Wieviorka (2006), assinala a necessidade de entendermos violência em sua face atual, chamando nossa atenção para seu enraizamento na história e nos processos sociais, 
pois suas expressões mudam e mudam as percepções e os comportamentos em relação a ela. Por exemplo, diz o autor que, com a globalização, caiu o número de conflitos armados no mundo, diminuíram os conflitos com mais de mil vítimas e os golpes de estado. No entanto, a criminalidade organizada, as guerras por razões étnicas, o terrorismo e as ameaças de guerra que utilizam os mais recentes desenvolvimentos da biologia, da bacteriologia, da química e da física nuclear cresceram. Tudo isso vem acompanhando grandes e inegáveis transformações no mundo, como o fim da Guerra Fria, a reestruturação produtiva e suas conseqüências para o declínio do movimento operário. A violência pós-industrial cria novos tipos de vitimização e de subjetividades. E ela se serve, sobretudo, da profunda revolução no campo da comunicação, da informação e da informática, que trouxe, dentre outras mudanças, a compressão do espaço e do tempo.

Ao sentido da mudança trazida pela globalização, pensada como circulação de dinheiro, do capitalismo sem fronteiras, dos fluxos financeiros e comerciais, contextos que 'ressituam' a problemática da violência, é preciso acrescentar a circulação mundial nos campos culturais, sociais e políticos e a combinação de dimensões mundiais, transnacionais e locais. Por exemplo, é assim que o terrorismo tornou-se global, pois sua forma atual combina dimensões planetárias, aspectos metapolíticos e ancoragem no seio das localidades onde os terroristas instauram suas idéias e suas células. Igualmente, o mesmo raciocínio se aplica às várias formas de crime como o tráfico de armas, de drogas e de seres humanos que são organizadas (e muitíssimo lucrativas) em escala transnacional, mas atuam em rede, ancoradas nos atores radicados em espaços locais. 
Wieviorka (2006), sem justificar a Guerra Fria, comenta que ela ofereceu uma 'certa contenção' política dos países dos dois blocos e do terrorismo. Conforme esse autor, o fim da Guerra Fria inaugurou um novo repertório de ações como violências militares, terrorismos e ameaças nucleares. Criou-se no mundo, sobretudo a partir do atentado de 11 de setembro nos Estados Unidos, seguido por outros igualmente ameaçadores como os de Madri e de Londres, uma sensação coletiva de instabilidade e de crise que atinge, sobretudo, as relações entre o Ocidente e o Oriente. A esse estado de conflitos sociais pósGuerra Fria, Samuel Huntington (não sem controvérsias) chamou choque de civilizações.

$\mathrm{O}$ foco da discussão para Wievioka, com relação à reestruturação produtiva e ao declínio do movimento operário, com o qual compartilho, é que no mundo contemporâneo, diferentemente da era industrial, faltam mecanismos de expressão de conflitos. A violência encontra espaço muito mais propício para se exprimir quando a realidade social não está estruturada por tipos de conflitos passíveis de serem tratados pelos atores. Por isso, considero que a violência é o contrário do conflito institucionalizado. Ela traduz a existência de problemas sociais que não se transformam em tema de debate e busca de solução pela sociedade.

No campo da subjetividade, que se pode entender como a capacidade do ser humano construir sua experiência e produzir suas escolhas, retomo, com Wieviorka, críticas às teorias que explicam a violência social e política ora como fruto de frustrações sociais, ora de cálculos racionais, ora de processos culturais. Todas essas abordagens são válidas em parte e ajudam a compreender o fenômeno, mas nenhuma delas leva em conta o imbri- 
camento do sujeito. É preciso dar relevo à lógica da perda e da sobrecarga, dos excessos e da falta de sentido que pervertem, preservam ou também asseguram a sobrevivência dos sujeitos no mundo pós-industrial e na atual 'sociedade dos indivíduos'. Nesse contexto, não é desprezível o papel da religião que justifica atos violentos, transcendendo aos parâmetros convencionais das instituições políticas.

Mas o mundo atual da globalização e da criminalidade em rede é também a era da demanda de reconhecimento, no espaço público, de identidades particulares e da exigência de reparação de injustiças ancestrais. É a era dos movimentos de mulheres, de homossexuais, de indígenas, de negros, de deficientes físicos ou de doentes mentais, de idosos, de descendentes de vítimas de genocídios, da cidadania de crianças e dos adolescentes, dentre outros. Esses personagens que foram crescendo como atores políticos no decorrer do século XX e, principalmente, no mundo depois da Segunda Guerra Mundial, ao se constituírem, passaram a influir na cena pública, transformando sua opressão e seu sofrimento em causas sociais. Eles chamam atenção para as conseqüências da violência para a integridade física, emocional e moral dos sujeitos e ressaltam seus efeitos para as gerações futuras.

Uma das mais fundamentais contribuições das demandas dos citados grupos e movimentos foi a de trazer para o cotidiano, para o chão da realidade existencial das pessoas comuns, a discussão da violência que, tradicionalmente, ocorria no plano das relações políticas formais. Ao colocar a subjetividade na discussão da violência, ressalto a importância de levar em conta a micropolítica, mostrando que ela afeta existências singulares e coletivas. Por isso é preciso que existam mecanismos e formas de proteção das vítimas de segregação e de discriminações na vida 
pública e privada, tanto quanto é necessária a segurança pública no sentido tradicional, voltada para conter a violência social.

Concluindo, sublinho que nem a filosofia popular nem os filósofos eruditos têm uma última palavra sobre o significado da violência. Muita gente defende um pensamento pragmático e maniqueísta sobre o tema: a violência é boa ou má, positiva ou negativa, segundo as forças históricas que a sustentam. Outros reafirmam sua negatividade sob qualquer pretexto. Exemplos estão aí, em pleno início do século XXI, inoculados pelo veneno do medo, da luta pelo poder e pelos bens escassos, para os quais a humanidade ainda não encontrou um antídoto. Ao contrário, vários chefes de Estado continuam a justificar conflitos políticos e guerras no mundo em nome da civilização e da paz. Igualmente, pais e mães ainda hoje persistem em abusar física e emocionalmente dos filhos por tradicionais e seculares razões ditas pedagógicas. 



\section{$2 \underset{\mid}{0}$ CONTEXto da ViolênCia Social}

O Brasil sempre teve uma história de violência articulada à sua forma de colonização e de desenvolvimento, embora, o mito que corre no imaginário social e é apropriado politicamente é de que somos um país pacífico. Trata-se de uma meia verdade. Ninguém duvida que o povo brasileiro seja acolhedor, hospitaleiro, generoso e solidário com seus patrícios e com estrangeiros. Essa constatação pode ser apreciada quando se observa o fato de que aqui conviverem pessoas dos mais diferentes lugares do mundo de forma cordata e civilizada, mesmo quando em seus países de origem a população esteja em situação de guerra ou em conflitos políticos. Pode-se assinalar, nesse sentido, como muito relevante, o caso dos judeus e árabes que, por diversas vezes, têm comparecido aos meios de comunicação, dando testemunho de sua inter-relação pacífica nos mais diferentes recantos do Brasil, sobretudo em cidades onde suas comunidades são maiores, como é o caso de São Paulo e Rio de Janeiro.

O outro lado da verdade, porém, é o de que somos um povo violento. Essa realidade é discutida por muitos estudiosos. Lucy Dias e Roberto Gambini (1999), por exemplo, questionam a ideologia escondida no mito da cordialidade. Gambini, que é filósofo, sociólogo e psicanalista, comenta que há muitos anos vem perscrutando a alma brasileira e, ultimamente, por ocasião da comemoração dos quinhentos anos do descobrimento do Brasil, colocou seus achados num 
livro elaborado em conjunto com a jornalista Lucy Dias. A obra se chama, Outros 500: uma conversa sobre a alma brasileira. Nela os autores discutem a tese de que nosso nascimento, como país, é fruto de um estupro: os homens (só havia homens - a maioria degradados - nas caravelas de Cabral) que aqui chegaram e encontraram as tribos indígenas, loucos para copular, não buscavam a alma das mulheres, nem a cultura autóctone, nem a sabedoria do povo.

Para os primeiros portugueses aqui advindos, a comunidade indígena era algo muito estranho, primitivo, pobre e selvagem. Para alguns, filosoficamente falando, os índios não eram iguais aos europeus. Pelo contrário, segundo o conhecimento e os preconceitos da época, os índios eram objeto de discussão quanto ao fato de terem alma ou não. Desta forma, nas mulheres índias, os portugueses buscavam apenas o prazer. Nos primeiros atos reais e simbólicos de geração do país, portanto, "faltou a mãe" no sentido freudiano do termo, dizem Dias e Gambini (1999), aquela na qual a criança mama a cultura. Ou no mínimo houve uma dissociação entre a cultura e a geração da vida.

A ausência de sintonia cultural, moral e espiritual entre um povo que chega como dominador e inicia uma miscigenação com o povo que aqui se encontra constitui o sentimento mais profundo que alimenta os vários tipos de segregação e crueldade que persistem na experiência nacional de quinhentos anos, sobretudo, contra a população pobre. Dias e Gambini problematizam e aprofundam também o papel da escravidão na construção da alma brasileira. Igualmente, as mulheres escravas foram usadas para o regozijo dos senhores e de seus filhos, criando-se, assim, uma geração em que a orfandade de pai (que 
negava sê-lo aos filhos de escravas) e da mãe (das quais os escravos eram separados para freqüentemente serem vendidos) real e simbólica fez parte da cultura escravocrata.

Poder-se-ia, a esta altura, até discutir que os portugueses foram menos cruéis que os espanhóis, no processo de colonização dos outros países da América Latina. No entanto, ainda que isso seja verdade, tal constatação não retira o fato de que o mito originário da criação do povo brasileiro seja marcado pela terrível violência do estupro. E todo o período colonial foi marcado pelo desprezo e pela crueldade contra os índios e os negros e pela exploração de sua força de trabalho e de sua cultura.

Ao apontar algumas reflexões do livro de Dias e Gambini, obra que é muito mais completa e complexa do que os fragmentos citados, quero dizer que, em qualquer época histórica do nosso país, a violência esteve e está presente. Deve, portanto, ser objeto de nossa reflexão, seja quanto à aculturação dos indígenas, quanto à escravização dos negros, às ditaduras políticas, ao comportamento patriarcal e machista que perpetua abusos contra mulheres e crianças, aos processos de discriminação, racismo, opressão e exploração do trabalho.

Uma das formas mais contundentes de violência no Brasil, que se poderia chamar estrutural e 'estruturante' pelo seu grau de enraizamento, são os níveis elevadíssimos de desigualdade que persistem historicamente e são o chão sobre o qual se assentam muitas outras expressões. O Brasil sempre foi marcado por ambivalências e ambigüidades de um país escravista e colonizado em que as relações sociais hoje estão entranhadas num tipo de apartheid considerado, por muitos autores, como mais iníquo que o dos Estados Unidos e o da África do Sul. 
Tendo feito esse recuo no passado, retomarei o momento presente. Seguindo a linha dos grandes movimentos políticos e ideológicos do Século XX, o Brasil viveu as lutas pelo socialismo, os efeitos da Guerra Fria, os sonhos de desenvolvimento e dois períodos de ditadura. A última, instaurada em 1964 e durando até 1979, constituiu um golpe de Estado e de Direito.

Também denominados Anos de Chumbo, essa etapa da história marcou provavelmente os mais obscuros momentos recentes do país e sepultou os sonhos desenvolvimentistas que eram acalentados por movimentos políticos e sociais. Dezoito milhões de brasileiros sofreram restrições impostas por aqueles que assumiram o poder, sobrepondo os chamados Atos Institucionais à Constituição brasileira. Por efeito dos ditos Atos, as liberdades individuais e os direitos políticos foram cerceados e suspensos, e os partidos políticos foram extintos. Houve confrontos e resistências, alguns deles marcados pela luta armada.

Como em outras ditaduras na América Latina, a população civil - a maioria formada por jovens - sofreu anos de repressão, aprisionamento e também a maior crueldade que se pode cometer contra o ser humano: a tortura. A tortura existiu em nome de uma razão de Estado que queria se impor à custa do aniquilamento das vontades individuais e coletivas ('pau de arara', 'afogamentos', 'geladeira', introdução de insetos nos órgãos sexuais, palmatória, enforcamento, ameaças sexuais, estiramento do corpo, 'churrasquinho' - queima de partes do corpo -, além de outras agressões físicas, morais e emocionais).

Nessa experiência de confronto armado entre militares brasileiros e militantes de movimentos políticos guerrilheiros ou de mera oposição, também não faltou o estupro de mulheres, como mostram livros e filmes sobre a época. É preciso ter em mente 
que a estratégia de humilhar os homens por meio da humilhação das mulheres vem ocorrendo nos mais diferentes momentos históricos e em diversas sociedades como arma de persuasão, como pode ser constatado nos relatos sobre as guerrilhas na Colômbia e como é o caso recente da Guerra de Kosovo em que cerca de 20 mil mulçumanas foram estupradas e aterrorizadas no processo de limpeza étnica liderado pelos sérvios.

A ditadura militar não poupou nossa sociedade. O Brasil saiu dessa experiência com mais desencantos que sonhos. Uma das conseqüências mais nefastas desse período foi o aprofundamento da cultura autoritária. Por isso, os elementos autoritários freqüentemente ressurgem nos comportamentos políticos, institucionais e nos microprocessos sociais, alimentando formas de violência social, de coronelismo, de patrimonialismo e de clientelismo. É claro que esses problemas têm raízes mais profundas, mas um dos grandes males da ditadura foi fazê-los florescer e se arraigar.

No entanto, no decorrer dos Anos de Chumbo também houve ganhos. Movimentos sociais com uma outra visão da realidade foram se formando e amadurecendo, contrapondose à repressão e ampliando a consciência coletiva, dentro de uma ótica de necessidade de investimento na questão social. Os anos 80 foram tempos de ouro do sindicalismo e para o desenvolvimento de associações civis e organizações não-governamentais (ONGs). Nessa mesma época, como se a caixa de Pandora explodisse, a par de uma crise econômica sem precedentes, começava-se a mostrar uma sociedade fundamentalmente urbana, conflituosa e com os problemas sociais não resolvidos pela ditadura, ao contrário, acirrados por ela. Sobretudo nos grandes centros urbanos, em lugar da violência política que a proposta de uma anistia 'ampla, geral e irrestrita' tentava dar instrumentos 
para superar, a violência social recrudescia e passava a se expressar de forma cruel por meio do crescimento abrupto das taxas de homicídio.

É fato que nos últimos 25 anos ocorreu uma escalada impressionante da violência social. É fato também que a abertura política brasileira coincide, historicamente, com o crescimento da globalização, com os acelerados processos de reestruturação produtiva e com o conseqüente aumento da exclusão social.

Em resumo, os problemas culturais estruturantes e seculares e as imensas desigualdades da sociedade brasileira, desde os anos 60 se acumularam e não foram superados, ao contrário, cresceram, dando forma a novas questões trazidas pela pósindustrialização e pela globalização. A presença da violência e da criminalidade na agenda da cidadania passa a ser ressaltada por ocasião do término (oficial) da ditadura militar. Os movimentos sociais pela democratização, as instituições de direito e a forte pressão de algumas entidades não-governamentais e organizações internacionais, com poder de influenciar o debate nacional, foram fundamentais para tornar a violência social uma questão pública, inclusive no interior do setor saúde. Mas esse novo ponto da agenda tem a ver também com a inflexão visível e contundente do crescimento das expressões de violência, sobretudo nas áreas urbanas. Passo a seguir a falar dos aspectos contemporâneos da violência social brasileira. 


\section{$3 \mid \begin{aligned} & \text { Um OLhar Sobre a Violência Social } \\ & \text { Brasileira }\end{aligned}$}

O tipo de violência que, neste momento histórico específico, invade o imaginário e a opinião pública brasileira, conforme teoriza Wieviorka (1997), tem características 'pós-modernas'. Suas manifestações são múltiplas e se tornam particularmente relevantes suas formas criminais e delinqüenciais. Por isso, ainda que os tipos mais tradicionais e seculares como as agressões e abusos intrafamiliares e comunitários conservem as mesmas características, essas estão subsumidas às expressões mais hegemônicas da história atual.

Ou seja, a violência de cunho coletivo, tal como se expressa hoje nas grandes cidades brasileiras, constitui-se, primordialmente, como condição de manutenção de negócios ilegais, freqüentemente de origem globalizada e que se beneficiam das facilidades geradas pelas revolucionárias transformações nos modos de produção de riqueza e dos aparatos técnico-informacionais e comunicacionais. Tem base econômica. As formas de gestão dos negócios criminosos ou violentos são, ao mesmo tempo, internacionalizadas, capilarizadas e em rede, funcionais à promoção de uma veloz circulação financeira, de produtos e de pessoas, à sombra da desregulamentação dos Estados nacionais e nos interstícios da ausência de regulação internacional. Elas possuem estratégias ao mesmo tempo internacionalizadas e culturalizadas pelos contextos locais.

Verdadeiras guerrilhas urbanas dos anos 90, as das gangues de narcotraficantes, por exemplo, apóiam-se em poderosos sis- 
temas de circulação e troca de produtos ilegais como drogas e armas e de lavagem do dinheiro. Portanto, é preciso ressaltar que no mundo da delinqüência pós-moderna, a forma mais hegemônica da violência coletiva no Brasil, segue a mesma lógica da globalização e se realiza em conluio com a legalidade. Wieviorka (1997) configura esse tipo de delinqüência utilizando os termos 'infrapolítica' e 'metapolítica' para explicar que ela se aproveita da crise de poder dos Estados nacionais e deseja cada vez mais o seu enfraquecimento (infrapolítica), ou mesmo se transforma na própria política de alguns Estados nacionais (metapolítica). Exemplificando a forma de agir do crime globalizado, Luiz Eduardo Soares (2002: 42) também fala do tráfico de drogas:

Em seu aspecto de atacado, o tráfico é uma articulação subreptícia de malhas internacionais, para as quais concorrem competências administrativas sofisticadas, conhecimento de equipamentos de última geração, acesso a línguas diversas e conhecimento de dinâmicas do sistema financeiro internacional.

Assim, a promiscuidade entre legalidade-ilegalidade, o caráter altamente lucrativo dos crimes e sua organização em rede configuram os fatores determinantes das formas contemporâneas de violência que, no Brasil, são responsáveis pelo aumento das mortes por homicídio e as taxas de criminalidade nos últimos 25 anos.

Um dos pontos mais perversos da delinqüência organizada é a forma de inclusão dos pobres e dos jovens nos seus lucrativos negócios. Eles se engajam nesses projetos e entram nos conflitos, no front dos combates como uma opção de mercado de trabalho, visando ao status, ao acesso a bens econômicos e ao consumo. $\mathrm{O}$ ato subjetivo de entrada no mundo do crime é 
secundado e contextualizado por uma situação de extremas desigualdades, de falta de oportunidade para o protagonismo, como cidadão, e de total descrença nas possibilidades de acesso ao consumo, à cultura e ao reconhecimento social. Por isso, o mercado da violência passa a se configurar como uma escolha viável, numa conjuntura de crescente desemprego e exclusão social, cultural e moral.

Apenas como um exemplo conjuntural, dados da Pesquisa Nacional por Amostra de Domicílios do Instituto Brasileiro de Geografia e Estatística (Pnad/IBGE) mostram que, em 2004, estavam empregados apenas $51,7 \%$ dos jovens na faixa de 18 a 19 anos (6,8 milhões) e somente $65,8 \%$ dos que têm 20 a 24 anos. Sabe-se que essas proporções de desempregados são muito mais elevadas entre os jovens pobres das periferias urbanas. São grupos populacionais inteiros excluídos do mercado de trabalho, exatamente numa etapa da vida em que, a história prova, estão exacerbadas as expectativas e as manifestações de revolta, de contestação e de violência. As expressões desse fenômeno na atualidade, como já foi dito, estão relacionadas à reestruturação produtiva, à exacerbação da acumulação capitalista e à ausência de ênfase na questão social por parte dos governos.

Essas situações que têm origem macroeconômica e social são acompanhadas pelo surgimento de novas subjetividades marcadas pela secularização, pela desvalorização das hierarquias tradicionais e da autoridade familiar e comunitária. O desencanto com a política e com a democracia, tal como ela é praticada em benefício dos próprios políticos e de grupos privilegiados, coroa o panorama propício à configuração da violência social brasileira contemporânea. 
Por se incluírem como a ponta do iceberg dos negócios ilegais, (sobretudo, de drogas e de armas de fogo) principalmente os jovens pobres, que se integram na sociedade por meio desse tipo de atividade, tentam se fazer presentes e visíveis, conquistar territórios e defender espaços. Geralmente, o processo de trabalho do mercado da violência em que se colocam exige deles tarefas desafiantes que realizam com disciplina militar, rígida hierarquia e sob o controle freqüente de ameaças, torturas, elevado risco de vida e sob a mira de poderosas armas de fogo. Do ponto de vista das relações de poder, essa população incluída pelo crime e excluída do mercado de trabalho legal, reproduz o que existe de mais autoritário e cruel nas estruturas de poder da sociedade brasileira.

No mercado de varejo do narcotráfico, a arma dá status aos jovens, ao mesmo tempo em que mudanças na organização vicinal afrouxaram o controle social informal, tradicionalmente exercido pelos mais velhos sobre os mais novos. Soares argumenta que são duas as moedas usadas nessa sedução dos jovens para o crime: a material e a simbólica. A primeira é trivial, diz o autor. A segunda é fundamental e, freqüentemente, subestimada pelos agentes responsáveis pela formulação de políticas de segurança: "Quando o tráfico oferece ao menino uma arma, dá a ele não apenas um instrumento de operação econômica, mas um instrumento de constituição subjetiva de afirmação de si mesmo, de recuperação de sua visibilidade, de imposição de sua presença social" (Soares, 2002: 43).

A violência que o jovem pobre e das periferias urbanas reproduz a partir de sua entrada em organizações criminosas tem relação com a violência do não-reconhecimento que o acompanha desde o nascimento. Continua Soares (idem): 
Esse menino pobre das metrópoles brasileiras, que não encontrou acolhimento na estrutura familiar, também não foi acolhido pela escola ou pela comunidade, a sociedade passa por ele como se ele fosse transparente, como se ele não tivesse nenhuma densidade ontológica, antropológica ou sequer, humana. Quando porta uma arma adquire presença, torna-se capaz de paralisar o interlocutor pelo medo, de fazer que o transeunte pare na frente dele, reconhecendo-o, afinal, como um sujeito.

Vários autores aprofundam a questão da intricada relação entre individualidade, subjetividade e circunstâncias sociais herdadas e fortemente influentes, lembrando que sempre existe o espaço de opção dos sujeitos, mas que, os possíveis sociais são muito limitados para eles. Dessa perspectiva, falarei mais detidamente quando tratar das interpretações dos teóricos do setor saúde. Nesse sentido são de grande relevância o estudo de Simone Gonçalves de Assis (1999) em que a autora mostra como vai se formando a subjetividade enfraquecida pela ausência real e simbólica do pai no contexto familiar, como se diferenciam as posturas dos jovens pobres numa mesma família em que irmãos optam pelo ingresso no crime e outros tentam se manter na busca de um lugar na sociedade 'legal' e como a origem social propicia o ambiente, mas não determina as escolhas.

Podemos concluir que as formas de delinqüência organizada no Brasil, classificadas pela Organização Mundial da Saúde (OMS) na categoria de violência coletiva (e que a população reconhece como a própria violência), presentes nos últimos 25 anos no Brasil, são subprodutos da esfera política: denunciam o fim de uma época desenvolvimentista e a decomposição dos sistemas sociais e dos aparatos formais que consolidaram o Estado nacional. Enunciam, também, a exacerbação de novas formas de so- 
ciabilidade, construídas com ingredientes que fazem parte de uma emergente ideologia dominante: a que mescla o consumismo com o hedonismo, o individualismo com o egocêntrico e o imediatismo. Tais valores (contravalores?) dificilmente poderão ser contidos pelas instituições de segurança pública, como se acreditava nas origens do Estado moderno, quando a elas foi conferido o monopólio da violência em nome da sociedade, para superar a tradição então vigente de fazer 'justiça pelas próprias mãos'.

É bem verdade que as expressões da violência que ocorrem hoje no Brasil são muito mais complexas, não se limitam à questão dos crimes que ocorrem nas áreas pobres das grandes cidades. No entanto, é sobre as condições e as circunstâncias da escassez de oportunidades e perspectivas - principalmente no caso da juventude bombardeada pelos apelos de consumo e pela falta de reconhecimento e de chances sociais - que se constroem as taxas de criminalidade e as conseqüências da violência, particularmente, nas regiões metropolitanas. 


\section{4 | Prejuízos, Lucros e Interesses}

Hannah Arendt tem uma expressão muito interessante quando disserta sobre o problema em discussão: a violência serve para dramatizar causas e trazê-las à consideração pública. Ou seja, a violência incomoda, é uma pedra no sapato e por isso obriga a todos os que estão acomodados em seu bem-estar a pensar que tudo o que ocorre pode estar relacionado com eles e ninguém escapa de seu raio de influência. No mundo em geral como aqui no país, os óbitos infligidos por outros ou autoinfligidos nos últimos anos se constituem em sério problema social e têm intensas repercussões na saúde pessoal e coletiva. Também os danos, as lesões, os traumas e as mortes causados por acidentes e violências correspondem a altos custos emocionais e sociais e com aparatos de segurança pública. Causam prejuízos econômicos por causa dos dias de ausência do trabalho, pelos danos mentais e emocionais incalculáveis que provocam nas vítimas e em suas famílias, e pelos anos de produtividade ou de vida perdidos.

Ao sistema de assistência à saúde, propriamente dito, as conseqüências da violência, dentre outros aspectos, infligem elevados gastos com estruturas pré-hospitalares, emergência, assistência e reabilitação, processos muito mais custosos que a maioria dos procedimentos médicos convencionais. Existem cálculos do Banco Interamericano de Desenvolvimento (BID), segundo os quais cerca de 3,3\% do Produto Interno Bruto (PIB) 
brasileiro é gasto com os custos diretos da violência, cifra que sobe para 10,5\% quando se incluem custos indiretos e transferências de recursos. Para se ter idéia do significado da cifra dos custos diretos da violência no Brasil (3,3\% do PIB), ela é três vezes maior do que o país investe em ciência e tecnologia. O sociólogo venezuelano Roberto Briceño-León (2002), comentando a situação na América Latina como um todo, e reportando-se a dados do BID de 1999, afirma que os danos e as transferências de recursos promovidos por causa da violência na região atingem a 14,2\% do PIB e equivalem a 168 milhões de dólares.

No entanto, a violência também dá lucro que pode ser aferido de várias formas. Primeiramente, uma parte das mortes e lesões que hoje ocorrem no mundo por essa causa se deve a ações criminosas organizadas internacionalmente para as quais os aparatos violentos garantem e agregam valor. É o caso do tráfico ilegal de armas, de drogas e de outras mercadorias. Atualmente, além de representantes de muitos segmentos da sociedade participarem de negócios ilegais promovidos pela criminalidade globalizada, esses estão totalmente imbricados com negócios legais de alguma maneira. Essa realidade vem sendo mostrada persistentemente pela mídia.

Além daqueles que lucram com comercialização de armas, de drogas, de seres humanos e de animais, dentre outros crimes e contravenções internacionais, há outros atores e grupos interessados no mercado da violência. São os que comercializam os sentimentos de insegurança da população. Dentre eles pode-se citar a grande quantidade de empresas e pessoas em atividades de segurança privada e em serviços de segurança patrimonial e pessoal que emprega um número muito mais elevado de funcionários que as instituições de segurança pública. É impressio- 
nante este fato, pois a instituição do Estado democrático tem a missão constitucional de prevenir e reprimir o crime. No entanto, a lista dos que tiram proveito da violência é ainda mais longa: as empresas que constroem os incontáveis dispositivos técnicos colocados em casas e condomínios, encarecendo os custos de moradia e, freqüentemente, segregando os moradores; as empresas que especulam com espaços de construção civil prometendo o paraíso e a paz; as indústrias de blindagem de carros, de produção de grades e de armas, dentre outros. Vários autores têm mostrado que o incremento da violência vem modificando a paisagem e a arquitetura das grandes cidades brasileiras.

Essas mudanças privilegiam os mais ricos que se isolam em paraísos fictícios, como se fosse possível não se exporem à realidade conflituosa das grandes metrópoles, marcadas pelo acirramento da questão social, sobretudo, do desemprego, da persistência das desigualdades e dos anseios frustrados da juventude que demanda oportunidades de vida e de consumo. Há, então, um círculo vicioso que alimenta as relações de acirramento entre os pobres que se sentem à mercê da violência social e os ricos que os tratam como se fossem 'criminógenos' e deles se isolando cada vez mais.

Em qualquer projeto ou proposta de superação da violência, é importante que a sociedade se pergunte sobre quem lucra com ela. Darei exemplo de um fato recente que pode esclarecer essa reflexão. Trata-se do processo lentíssimo e cheio de contradições ocorrido no Congresso Nacional, visando à aprovação do Estatuto do Desarmamento. Esse projeto que, finalmente, foi aprovado em 2005, ficou parado ou indo e voltando para pauta legislativa durante onze anos. Numa campanha para o plebiscito a respeito de apenas um item dele, o que tratava da proibição de 
comercializar armas, os debates e confrontos públicos foram absolutamente acirrados, dando ganho de causa aos senhores dos negócios. Foi muito difícil argumentar e convencer a população - frente ao agressivo marketing que explorou o 'direito do cidadão de ter esse bem de consumo’ - que não se pode falar das elevadíssimas taxas de homicídio no Brasil hoje sem que venha à tona a evidência do envolvimento e da contribuição das armas de fogo. Essa tecnologia, poderosamente maligna, movimenta um dos maiores e mais lucrativos mercados da economia global. O comércio de armas de fogo é o segundo mercado mais lucrativo do mundo, depois do petróleo. E os mapas da violência no Brasil mostram o crescimento das taxas de homicídios nos últimos 25 anos, acompanhado, paralela e concomitantemente, do aumento do uso de armas de fogo nas mãos da população.

Continuarei explorando o exemplo da campanha dos negócios de armas para falar dos interesses que exploram a violência. Esse mercado da 'morte' vive das guerras e da violência social e se tornou muito mais poderoso e eficiente no século XX. Interpretando a ascensão do poder das armas, o grande pensador francês Albert Camus, já na década de 1960 chamava o século XX de "o século do medo", ao contrário do século XVII que é lembrado pelo desenvolvimento das matemáticas, do século XVIII que consagrou as ciências físicas e o século XIX, considerado o século da biologia. Para Camus (1960), o medo é uma técnica de quem não pretende convencer o adversário e sim esmagá-lo pela força das armas ou por ideologias. Este autor referia-se ao fascismo, ao estalinismo e ao nazismo, mostrando também a perversa introjeção dos valores dessas ideologias autoritárias e cruéis nos sujeitos. 
É bem verdade que as armas de fogo por si não promovem a violência, como espertamente diz a publicidade que defende as armas. Porém, como revela o quadro de morbi-mortalidade por violência no Brasil, elas são o meio mais poderoso, hoje, para a produção de mortes, sobretudo, de jovens e adolescentes, tornando nosso país um dos campeões de homicídio no mundo. Estudos feitos por Fernanda Peres do Centro de Estudos da Violência da USP para o Ministério da Saúde (Brasil, 2004) evidenciam que acima de $60 \%$ dos assassinatos ocorridos em áreas urbanas brasileiras na década de 1990 foram cometidos com o uso desses aparatos. Igualmente, a Organização Mundial de Saúde (OMS) estimou que 2.3 milhões de mortes violentas no mundo no ano 2000 envolveram armas de fogo, várias centenas de milhares tendo resultado em homicídios, suicídios e óbitos em conflitos bélicos. A partir de informações sobre 52 países com rendas alta e média, a OMS calculou que cerca de 115.000 pessoas morreram por ferimentos causados por arma de fogo em apenas um dos anos da década de 1990. Desses óbitos, 79.000 (69\%) foram homicídios e mais de $80 \%$ vitimaram homens, principalmente nas faixas jovens de 15 a 44 anos de idade (OMS, 2002).

Um dos mais fortes argumentos ideológicos usados para convencer a população, pelos que não queriam abrir mão da produção e da comercialização de armas de fogo, é que a arma é um instrumento de segurança e deve ser usado para defesa pessoal, numa sociedade fragilizada pela violência. Proibir o civil de comprar uma arma, para os que pensam assim, é o mesmo que privá-lo da sua única e última possibilidade de reagir aos horrores da violência 'dos outros', a violência social. Esse argumento interesseiro, no entanto, não se sustenta em estudos de 
várias áreas e de vários autores, sobretudo os do campo da saúde pública. Nos Estados Unidos, por exemplo, pesquisas dos Centros para a Prevenção e Controle das Doenças (em inglês, Centers for Diseases Control and Prevention - CDC), calculam que, ter uma arma de fogo em casa, tem potencializado às pessoas que a possuem, 43 vezes mais a matarem ou a ferirem alguém, inclusive membros da própria família. Sem a mediação das armas, as pessoas se vêem obrigadas a discutir, a argumentar e, mesmo quando se agridem fisicamente, geralmente, não chegam a tirar a vida do contendor.

Outro argumento muito freqüente a favor da comercialização de arma foi de que as pessoas de bem ficariam prejudicadas com a sua proibição, pois os bandidos e delinqüentes continuariam a obtê-las pelos meios ilegais, como sempre agiram. Essa visão é verdadeira em parte. É claro que os bandidos nunca entregarão as armas, elas têm que ser tomadas deles pelas forças de repressão ao crime. Os que vivem do mercado da violência, inevitavelmente, continuarão a comprar armas ilegalmente e, principalmente, a roubá-las dos cidadãos que vivem na legalidade. Mas este é um assunto que deve ser tratado pela polícia e pela justiça criminal. A outra parte do argumento não é verdadeira: as pessoas de bem não ficam prejudicadas com a proibição da comercialização desses instrumentos de morte. Infelizmente, mais da metade dos crimes cometidos com armas acontecem fora do confronto com os bandidos e sim, nos espaços onde vive, trabalha e se diverte a população comum. Elas costumam ser usadas para dirimir conflitos interpessoais. Muita gente morre nas desavenças, nas brigas de vizinhos, nas contendas conjugais e, sobretudo, depois de bebedeiras nos bares, quando as pessoas perdem o controle emocional. 
Parte I I

Violência e Saúde Pública 



\section{$5 \begin{aligned} & \text { Violências e Acidentes na Pauta do } \\ & \text { Setor Saúde }\end{aligned}$}

Por ser um fenômeno sócio-histórico, a violência não é, em si, uma questão de saúde pública e nem um problema médico típico. Mas ela afeta fortemente a saúde: 1) provoca morte, lesões e traumas físicos e um sem-número de agravos mentais, emocionais e espirituais; 2) diminui a qualidade de vida das pessoas e das coletividades; 3 ) exige uma readequação da organização tradicional dos serviços de saúde; 4) coloca novos problemas para o atendimento médico preventivo ou curativo e 5) evidencia a necessidade de uma atuação muito mais específica, interdisciplinar, multiprofissional, intersetorial e engajada do setor, visando às necessidades dos cidadãos. Nos últimos anos, o setor saúde introduziu o tema em sua pauta, consciente de que pode contribuir para sua discussão e prevenção.

Violências e acidentes, ao lado de enfermidades crônicas e degenerativas configuram, na atualidade, um novo perfil no quadro dos problemas de saúde do Brasil e do mundo. Esse novo perfil ressalta o peso do estilo de vida, das condições sociais e ambientais e da maior longevidade, exigindo novas abordagens com as quais o sistema de saúde geralmente não está acostumado. É bem verdade que desde as décadas de 1960 e 70 houve um grande esforço teórico-metodológico e político dos estudiosos e profissionais para compreender a saúde como uma questão ampliada. No entanto, 
nunca um tema provocou e continua a provocar tantas resistências em relação a sua inclusão na pauta do setor como o das violências e acidentes.

Tratarei de dois aspectos: 1) a dinâmica social e setorial de inclusão e de paulatina legitimação do tema no âmbito interna cional e nacional do campo da saúde; e 2) uma descrição analítica sobre documentos, planos de ação e iniciativas brasileiras que demonstram a trajetória sinuosa, lenta, mas persistente de legitimação do problema no interior do pensamento e das práticas de saúde, oferecendo parâmetros, diretrizes e exemplos de possibilidades.

Existem inegáveis evidências da importância dessa problemática para a área da saúde. A OMS que, em 1993, escolheu a prevenção de traumas e acidentes como mote da celebração do Dia Mundial da Saúde, repetia em sua justificativa uma frase atribuída a William Forge, segundo o qual: "desde tempos imemoriais, as doenças infecciosas e a violência são as principais causas de mortes prematuras" (OMS, 1993, 5). Mais recentemente a organização revelou, em seu Relatório Mundial sobre Violência e Saúde, que "todo ano mais de um milhão de pessoas perdem a vida e muitas outras sofrem lesões não fatais", por causas violentas (OMS, 2002: 20). Só no Brasil, somente na década de 1990, mais de um millhão de pessoas morreram por violências e acidentes e dessas, cerca de 400 mil faleceram por homicídios. Tanto no mundo como aqui no país, os óbitos infligidos por outros ou auto-infligidos constituem sério problema social e têm intensas repercussões na saúde pessoal e coletiva.

Apesar de todas as razões citadas, a inclusão da violência na pauta do setor saúde vem ocorrendo muito lentamente. A primeira forma de introdução do tema, aquela à qual se refere 
William Forge, vem se dando, secularmente, dentro da própria lógica biomédica no atendimento pontual e específico das lesões, traumas e mortes. Essas categorias são tradicionalmente contempladas na Classificação Internacional das Doenças (CID) com a denominação 'causas externas'. O conceito de mortalidade por causas externas sempre incluiu os homicídios, os suicídios e os acidentes; e o de morbidade, as lesões, os envenenamentos, os ferimentos, as fraturas, as queimaduras e intoxicações por agressões interpessoais e coletivas.

A sensibilização em relação ao tema como pauta para ação de saúde se iniciou pioneiramente com o problema das violências contra crianças. Embora existam alguns documentos históricos que mostram, desde a Antiguidade, uma preocupação da sociedade em regular a subministração de castigos e maustratos na infância, os primeiros textos que vinculam esse tipo de violência com a saúde, procedem dos levantamentos de Tardieu em 1880 (Assis, 1994).

Nos anos 60, por meio de textos e debates, os profissionais de saúde começaram a fazer denúncias sistemáticas sobre as várias modalidades de violência contra crianças e adolescentes e sua influência negativa para o crescimento e o desenvolvimento das vítimas. Uma década depois que os pediatras Kempe e colaboradores (1962) cunhassem a expressão "síndrome do bebê espancado", vários profissionais passaram a reconhecer e a diagnosticar esse tipo de agravo como um problema de saúde. Programas de prevenção primária e secundária e intervenções, principalmente, nas dinâmicas familiares responsáveis pela maioria das agressões, negligências e abusos psicológicos, se instituíram na pauta de serviços de instituições públicas, privadas e organizações não-governamentais (ONGs). 
Diferentemente da militância que brotou da corporação médica na última metade do século XX, denunciando e buscando solução contra os abusos que vitimam crianças e adolescentes, a introdução da violência contra a mulher na agenda da área da saúde ocorreu pelo protagonismo do movimento feminista. Com uma estratégia voltada para criar consciência de gênero nos mais diferentes ambientes e instituições, esse movimento pressionou e continua a pressionar o setor saúde para que atue ativamente e dê respostas concretas não apenas para o tratamento das lesões e traumas provenientes da violência, mas para agir nas causas, por meio de uma pauta positiva de ações.

Foram endereçados à área da saúde os mais diferentes problemas que afetam a vida e a integridade das mulheres, como agressões conjugais, mutilações, abusos sexuais, físicos e psicológicos, homicídios e uma série de sintomas físicos e psicossomáticos associados à violência de gênero. A força do feminismo na abordagem do diagnóstico situacional e nas propostas de ação, relativas a gênero, aparece claramente nos documentos dos organismos internacionais do setor saúde, como o que apresenta as conclusões da Conferência sobre Violência e Saúde realizada pela Organização Pan-Americana da Saúde em Washington em 1994 (Opas, 1994).

O tema dos maus-tratos contra idosos foi pela primeira vez nomeado em um periódico inglês em 1975, por meio da categoria “espancamento de avós” (Baker, 1975; Burston, 1975). Mais recentemente o assunto vai tendo relevância na bibliografia internacional, nacional e nas práticas de proteção, prevenção e atenção. $\mathrm{Na}$ área da saúde, os estudos e ações são ainda muito tímidos, mesmo na literatura de países onde tradicionalmente existe forte tradição de pesquisa. 
Em toda a sociedade ocidental, e mais particularmente no Brasil, é na década de 1980 que o tema da violência entra com mais vigor na agenda de debates políticos e sociais e no campo programático da saúde. Oficialmente, somente a partir da década de 1990, a Organização Pan-Americana da Saúde (Opas) e a OMS começaram a falar especificamente de violência (e não apenas, causas externas), congregando as várias discussões (sempre dispersas e com pouca legitimidade institucional) que vinham ocorrendo nos diferentes âmbitos e em alguns países.

Em 1994, a Opas convocou os ministros de Saúde das Américas, pesquisadores e especialistas, para uma conferência sobre o tema. Nos documentos preparatórios e no documento final do evento, estão incluídos os aspectos tradicionais que sempre marcaram a atuação do setor e várias outras problemáticas que, pela primeira vez, foram incluídas na pauta, de forma orgânica. Os participantes da Conferência entenderam que a transição epidemiológica dos países da região apresentava uma questão antiga com novas cores e era preciso defini-la na sua especificidade histórica e mapeá-la, para que fosse tratada com as distinções próprias do setor e nos aspectos da intersetorialidade.

A violência, pelo número de vítimas e pela magnitude de seqüelas orgânicas e emocionais que produz, adquiriu um caráter endêmico e se converteu num problema de saúde pública em muitos países (...). O setor saúde constitui a encruzilhada para onde convergem todos os corolários da violência, pela pressão que exercem suas vítimas sobre os serviços de urgência, atenção especializada, reabilitação física, psicológica e assistência social. (Opas, 1994: 3)

Em 2002, a OMS produziu um Relatório Mundial(2002) em que o termo 'causas externas', que tradicionalmente englobava 
'acidentes e violências' e era usado para categorizar o tema na Classificação Internacional das Doenças, foi substituído pela expressão 'violência e saúde'. Neste documento, a OMS não trata do conceito de 'acidentes' por considerar que neles não está presente a 'intencionalidade', termo que determina a concepção de violência e dos atos violentos.

Em 1997, a OMS já havia realizado uma Assembléia Mundial com ministros de Saúde de todos os países-membros da Organização das Nações Unidas (ONU), em que esse assunto fazia parte dos temas relevantes. E, em suas recomendações para a região das Américas, a redução da violência já entrara como uma das cinco primeiras prioridades. No documento de 2002, porém, aprofunda todos os aspectos desse último fenômeno, deixando clara para todo o setor saúde a opção de adotá-lo em sua pauta de ação, merecendo definições, categorizações, problematizações e encaminhamentos. Análises minuciosas (embora de caráter aglomerado) foram apresentadas e no relatório há uma série de recomendações para todo o setor.

Uma das recomendações foi que cada país fizesse seu próprio diagnóstico e plano de ação. Atendendo a esse chamado, em 2005, o Ministério da Saúde, junto com a representação brasileira da Opas e do Centro Latino-Americano de Estudos de Violência e Saúde Jorge Careli (Claves-Fiocruz), produziram e divulgaram um relatório, seguindo mais ou menos a linha do texto internacional, denominado "Impacto da violência na saúde dos brasileiros" (Brasil, 2005b). Além disso, o Ministério da Saúde do Brasil está implantando um plano de ação como será visto adiante. É preciso que neste contexto fique clara a idéia de que o setor saúde quando assume a violência como um dos mais importantes agravos à saúde da população mundial o faz 
num tom diferente da lógica com que trabalham os cientistas políticos e as forças de segurança pública. A saúde pública está preocupada com as vítimas e não com a repressão, não no sentido de inocentar ninguém, mas de atuar na promoção da vida e da qualidade de vida. 



\section{6 | Iniciativas do Setor Saúde}

O reconhecimento do problema da violência pela área da saúde no Brasil vem se fazendo de forma fragmentada, lenta, intermitente, mas progressiva. Primeiramente trouxeram o problema ao debate, pediatras, epidemiologistas e psiquiatras. Os primeiros, seguindo as trilhas de Kempe e colaboladores, como já foi mencionado; os segundos, produzindo importantes estudos de magnitude e evidenciando tendências; os últimos, analisando as relações das agressões com as enfermidades mentais, com ênfase em estudos sobre suicídio. Seus trabalhos se iniciam nos anos 70, mas o incremento maior da contribuição científica da área sobre o tema vem ocorrendo a partir dos anos 80 até o momento presente. $\mathrm{O}$ aporte dos estudiosos da área da saúde na produção científica sobre violência, nos últimos 25 anos, cresceu $90 \%$ em relação a tudo que se tem registrado em qualquer período histórico anterior (Minayo, 1990; Minayo \& Souza, 2003).

Do ponto de vista da atuação, alguns pediatras iniciaram atividades assistenciais e de prevenção nos hospitais em que trabalhavam e algumas ONGs foram construídas por eles, com o propósito de tratar de temáticas peculiares, dentro de propostas que incluíam e também, ultrapassavam os marcos tradicionais do setor saúde. Assinalo, como relevante, o pioneirismo das atividades dos Centros Regionais de Atenção aos Maus-Tratos na Infância (Crami), em São Paulo; da Associação Brasileira Multiprofissional de Proteção à Infância e à Adolescência (Abrapia) 
no Rio de Janeiro e da Associação Brasileira de Prevenção aos Abusos e Negligências na Infância (ABNAPI), em Minas Gerais. Esses exemplos surgidos nos anos 80 e que se somam hoje a um sem-número de iniciativas, foram fundamentais no processo de legitimação do tema na sociedade e no setor saúde.

No âmbito da proteção à infância, profissionais comprometidos com a saúde e com o desenvolvimento integral das crianças e adolescentes participaram ativamente de um forte movimento em prol da cidadania desse grupo, o que redundou na criação do Estatuto da Criança e da Adolescência (ECA) promulgado em 1990. Hoje existe um número bastante grande de programas e iniciativas da sociedade e do Estado que focalizam o problema. Um documento importantíssimo da Secretaria de Estado dos Direitos Humanos do Ministério da Justiça com caráter intersetorial e, portanto, contando com a contribuição do Ministério da Saúde e de profissionais da área, é o Plano Nacional de Enfrentamento da Violência Sexual Infanto-Juvenil de 2002. Nesse plano, não só foi feito um diagnóstico da situação, como se criaram condições para defesa de direitos das crianças e adolescentes vítimas e de responsabilização dos pais e cuidadores responsáveis, de normas de atendimento e de prevenção. Construíram-se, também, indicadores para monitoramento e comprovação da efetividade da ação nacional.

A participação do movimento de mulheres brasileiras, na introdução da violência de gênero na pauta do setor saúde no Brasil, teve uma expressão fundamental na construção do Programa de Atenção Integral à Saúde da Mulher (PAISM), promulgado em 1983. O programa incorpora de forma clara a pauta dos direitos sexuais e reprodutivos, cuja reflexão sobre a violência de gênero tem lugar de destaque. O PAISM leva em 
conta a relevância do tema da violência e oficializa um tipo de olhar específico para o problema em todo o serviço público. É importante acrescentar que o lançamento, em 2004, da Política Nacional de Direitos Sexuais e de Direitos Reprodutivos e um plano de ação que contempla o período de 2004 a 2007, aprofunda as proposições do PAISM. De acordo com os princípios e diretrizes dessa política e do plano de ação, o Ministério da Saúde estabeleceu como meta aumentar o número dos serviços de atenção às mulheres e às adolescentes em situação de violência nos municípios pólos de microrregiões, apoiando-se na organização de redes integradas.

A promulgação do Estatuto do Idoso pela Secretaria Especial de Direitos Humanos, em 2003, trouxe o tema da violência contra esse grupo etário como pauta das políticas sociais. Em 2005 foi oficializado um plano de ação intersetorial de enfrentamento da violência contra a pessoa idosa. Ao setor saúde cabe realizar ações de promoção, de prevenção de agravos, de atendimento às várias formas de violência e de normalização das casas e clínicas de longa permanência.

Já na metade dos anos 90, muitas secretarias de saúde municipais, em articulação com organizações da sociedade civil, haviam criado estratégias e serviços de prevenção e de assistência às conseqüências da violência. Tais iniciativas se multiplicaram desde então, geralmente, congregando instituições públicas, ONGs e institutos ou grupos de pesquisa.

Em 1998, o Conasems (Conselho Nacional dos Secretários Municipais de Saúde), com a assessoria do Claves, instituiu um plano de ação de prevenção da violência contra crianças e adolescentes, em parceria com a Unicef e a Unesco, incluindo orientações gerais para o conjunto dos municípios. Nos últimos 
quatro anos, essa organização passou, também, a fazer parte, como âncora, da Rede Gandhi, instituição que se dedica ao tema da não-violência e da cultura da paz. Incontáveis municípios aderiram à Rede, individualmente, pautando ações e adequando a estrutura dos serviços para a promoção da cidadania e prevenção da violência nos mais diferentes níveis: familiar, comunitária, social e, também, atuando em relação às violências produzidas pelas próprias instituições e profissionais de saúde.

Ainda em 1998, o Ministério da Saúde instituiu um grupo de trabalho para assessorá-lo na formulação de uma Política Nacional de Redução de Acidentes e Violências. Em maio de 2001, culminando o longo processo de reflexão, foi promulgada uma portaria do Ministério da Saúde, oficializando o documento de definição da política, com desdobramentos em todas as áreas de atenção à saúde, informação em saúde, bem como nas linhas de prevenção (Brasil, 2001). E, recentemente, em 2005, foi também promulgado um plano de ação setorial. Desses dois últimos dispositivos falarei mais detalhadamente. Essa e as outras iniciativas dos órgãos públicos foram todas pressionadas ou articuladas por movimentos sociais, internacionais, por intelectuais e por técnicos e profissionais do setor, que passaram a não só evidenciar a magnitude do problema como a propor estratégias, em diferentes níveis, para reduzi-lo ou superá-lo.

O documento da Política Nacional de Redução de Acidentes e Violência, aprovado por portaria do Ministro da Saúde em maio de 2001, em primeiro lugar trata o tema em pauta como um problema social e histórico, e o situa nos marcos da promoção da saúde e da qualidade de vida. É nesse mesmo sentido que define o conceito de 'violência' e o distingue de 'acidentes', (uma vez que tradicionalmente esses dois termos vêm juntos na 
CID sobre causas externas). A seguir faz um diagnóstico geral do problema, das formas como ele afeta o setor saúde e como esse próprio setor, por ser parte da sociedade em que a violência está configurada, também a gera e a reproduz. Analisa as fontes de informação e documentação oficial existente, sua importância e suas deficiências (Brasil, 2001).

O diagnóstico situacional, embora referencie dados aglomerados que dizem respeito ao país como um todo, apresenta detalhadamente as várias manifestações do problema (agressão física, abuso sexual, violência psicológica, omissões, violência interpessoal, institucional, social, no trabalho, política, estrutural, cultural, criminal e de resistência). Também distingue as formas diferenciadas com que a violência incide em homens e mulheres e nas diversas faixas etárias. Analisando esse texto oficial, observa-se um processo crescente de tomada de consciência sobre o problema, deixando aberturas para novas inserções. Por exemplo, quando foi escrito, programas ministeriais que levassem em conta as violências e discriminações por raça/etnia/cor e opção sexual (a não ser no tema específico da Aids) e que apresentassem necessidades especiais eram quase inexistentes. Desta forma, a Política Nacional embora não trate esses assuntos, abre espaço para a sua inclusão.

O documento em pauta descreve e analisa também as várias leis, portarias, normas e dispositivos setoriais e intersetoriais que fazem interface e interagem com as informações do setor saúde e sua prática, como é o caso, em termos de legislação, do Código Nacional do Trânsito promulgado em 1997. Quanto aos dispositivos, o texto trata da Declaração de Óbitos, do Boletim de Ocorrência Policial, do Boletim de Registro de Acidentes de Trânsito; da Comunicação de Acidente de Trabalho (CAT). 
E sobre os dados existentes, refere-se ao Sistema de Informações sobre Mortalidade (SIM), ao Sistema de Informações Hospitalares (SIH) e ao Sistema Nacional de Informações TóxicoFarmacológicas (Sinitox) do SUS. O texto apresenta, como constatação, que inexiste um sistema nacional que sistematize e analise os acidentes de trânsito. $\mathrm{O}$ mesmo ocorre com as informações da área de segurança pública. Comenta que as CAT, por sua vez, são insuficientes, pois apenas informam os dados dos acidentes e violências nos locais de trabalho para os empregados que possuem carteira assinada. Essa deficiência tem um impacto muito forte, tanto na sistematização de dados como na oferta de serviços à população, pois mais da metade dos ocupados no Brasil, atualmente, está na informalidade, o que se acirrou com a reestruturação produtiva.

Os princípios que fundamentam o documento de Políticas são os mesmos que orientam o SUS: 1) saúde como direito fundamental e como requisito para desenvolvimento social e econômico; 2) direito ao respeito à vida como valor ético; 3) promoção da saúde como fundamento de qualquer ação para redução das violências e acidentes. Esses princípios fundamentam os planos a serem construídos nos níveis nacional, estadual e municipal.

As diretrizes condizentes com os princípios assim se resumem: 1) promoção da adoção de comportamentos e ambientes seguros e saudáveis; 2) monitoramento da ocorrência de acidentes e violências; 3) sistematização, ampliação e consolidação do atendimento pré-hospitalar; 4) incremento de uma forma de assistência multiprofissional às vítimas de violência e acidentes; 5) estruturação e consolidação dos serviços de recuperação e reabilitação; 6) investimento na capacitação de recursos huma- 
nos, em estudos e em pesquisas específicas, sobretudo nos assuntos que possam iluminar as práticas nos três níveis, principalmente, o local.

No documento também distribuem-se responsabilidades institucionais, tendo como critério a articulação intersetorial nos âmbitos dos governos federal, estaduais e municipais, e com a sociedade civil, nas áreas de desenvolvimento urbano, justiça e segurança, trabalho, emprego e previdência social, transportes e ciência e tecnologia. Cita-se, especificamente, o papel das universidades, afirmando que elas não podem ficar alheias a este problema que hoje afeta profundamente a sociedade brasileira. Propõe-se, para isso, que promovam formação de recursos humanos para lidar com as questões específicas de violência e atuem em pesquisas de caráter estratégico para que haja impacto positivo sobre os problemas tratados, a partir de diagnósticos cientificamente informados.

Por fim, o documento em discussão dedica um capítulo ao tema do acompanhamento e da avaliação como uma forma de atuar na implantação e na implementação monitorada da política pública, sobretudo pelo fato de a violência ser um tema relativamente novo no setor saúde. Esse monitoramento necessita ser encarado de forma muito diferente do que é tradicional nos processos de vigilância epidemiológica convencional. A violência não é uma doença e nem uma epidemia. Como fenômeno social, os indicadores de prevenção e de êxito precisam ser delineados com parâmetros de inclusão social (ressaltando a importância da inclusão dos cidadãos também nos benefícios do setor saúde) e de promoção da cidadania. Sabiamente, o texto fala da necessidade de desenvolvimento de parâmetros, critérios e metodologias específicas, acompanhamento das experiências e avaliação periódica. 
É preciso ressaltar que o texto que apresenta a Política foi escrito por uma equipe de especialistas de várias áreas (seguindo o critério de que a violência é um problema complexo e qualquer atuação precisa ser desempenhada de forma intersetorial), junto com técnicos do Ministério da Saúde. Antes de ser promulgado, seu conteúdo passou por um abrangente seminário nacional com estudiosos, profissionais que atuam nos vários tipos e níveis de atendimento na área de saúde e membros da sociedade civil. Por isso, configura uma produção coletiva. Depois desse processo, o documento foi encaminhado à Comissão Tripartite e aprovado por essa instância do SUS que reúne os mais importantes representantes do Ministério da Saúde, os residentes do Conass (Conselho Nacional dos Secretários Estaduais de Saúde) e do Conasems. Em abril de 2001, o Conselho Nacional de Saúde confirmou o parecer da Tripartite e, em maio, o texto foi aprovado oficialmente por meio da Portaria MS/GM n. 737 de 16/5/2001, publicada no Diário Oficial n. 96 , seção 1 e, de 18/5/2001.

A partir do momento em que o Ministério da Saúde promulgou a portaria que oficializa sua filosofia, suas diretrizes e sua linha de atuação foi organizada, em seu âmbito, uma Área Técnica para Acidentes e Violências., cujo objetivo tem sido mobilizar, articular e pactuar ações integradas intra e intersetoriais, orientando parcerias técnicas, institucionais e financeiras para a estruturação de uma rede nacional de enfrentamento da questão. Foi construído um programa de Redução de Morbi-mortalidade por Acidentes de Trânsito com recursos do DPVAT (seguro de danos pessoais causados por veículos automotores de vias terrestres). Vêm sendo incentivadas várias ações locais em estados e municípios, dentre elas, a de implantação de um progra- 
ma específico para coleta de dados, incluindo variáveis que não vinham sendo levadas em conta nos sistemas tradicionais. E também realizaram-se seminários macrorregionais sobre violência urbana e saúde pública em parceria com o Ministério da Saúde, com o Conselho Nacional de Saúde e com Congresso Nacional, em 2002.

Um dos passos mais importantes, no entanto, foi a formulação do Plano de Ação, iniciado em 2003, e implantado e implementado em 2005 (Brasil, 2005a). O processo de sua construção envolveu muitos atores governamentais e não-governamentais. Esse Plano, oficializado pela Portaria 936 do Ministério da Saúde, de 18/5/2004, dispõe sobre a estruturação da Rede Nacional de Prevenção da Violência e Promoção da Saúde e a Implantação e Implementação de Núcleos de Prevenção à Violência em Estados e Municípios. Para a formulação desse instrumento, inicialmente, realizou-se um diagnóstico, em que foi utilizado um indicador composto, por meio do qual o Ministério da Saúde estabeleceu um ranking dos municípios com mais de 100.000 habitantes em que a situação de violência (configurada por taxas de mortalidade por homicídios, acidentes de trânsito e suicídio) fosse mais dramática.

Por contar com parcos recursos orçamentários para a execução do plano, a Secretaria de Vigilância em Saúde do Ministério da Saúde, responsável pelo programa de redução de acidentes e violências está localizado, contemplou: 1) os quarenta primeiros da lista; 2) os municípios onde vinham sendo desenvolvidas ações do Programa de Ação Integrada de Enfrentamento da Violência Sexual Infanto-juvenil no Território Nacional (Pair); 3) os municípios de fronteira, onde se realizavam ações integrais de prevenção da violência e promoção da saúde e 4) estados com 
mais de um município selecionado pelos critérios anteriormente. Todos contam com fundos para a criação de Núcleos de atuação, de formação de recursos humanos e de desenvolvimento de pesquisas, tendo seu funcionamento orientado por diretrizes do documento da Política Nacional de Redução de Acidentes e Violências.

A configuração dessas iniciativas ocorreu durante o ano de 2005 e vem se implementando em 2006. Foram criados também, como parte do Plano, Núcleos em universidades das distintas regiões do país, com missões diversas, de acordo com suas competências e com uma encomenda específica do Ministério da Saúde para cada uma: criação de redes, apoio na formação de recursos humanos, desenvolvimento de pesquisas, monitoramento da implantação de ações em municípios e avaliação de ações de redução. Essa iniciativa está hoje, pois, em processo de implantação e implementação e, certamente, serão necessários pelo menos dois a três anos para que as atividades apresentem resultados.

É preciso assinalar também que, a partir de 2004, começaram a ser publicados editais específicos da Secretaria de Ciência e Tecnologia do Ministério da Saúde, em convênio com o Conselho Nacional de Desenvolvimento Científico e Tecnológico $(\mathrm{CNPq})$, visando a produzir pesquisas estratégias sobre a problemática. Precedido de um seminário que reuniu especialistas de todo o país, para estabelecer prioridades, os temas propostos para investigação corresponderam às amplas necessidades de conhecimento nacional e local, sendo que os resultados dessa inflexão sobre o tema, deverão ser conhecidos ao final de 2006, pois o edital selecionou os primeiros projetos para serem realizados em dois anos, 2005-2006. 
Em resumo, no período de 2001 a 2006, o Ministério da Saúde apresentou importante evolução na legitimação da Política Nacional de Redução da Morbi-mortalidade por Acidentes e Violências. Além dos documentos que são estruturantes da ação ministerial e do SUS, outros foram elaborados e oficializados, buscando-se a integração no tema nas ações rotineiras do setor: 1) Portaria 1.968/2001 que trata da notificação obrigatória pelos profissionais de saúde das situações de suspeita ou confirmação de maus-tratos contra crianças e adolescentes; 1) Portaria 1.969/2001, que dispõe sobre o registro e o preenchimento da Autorização de Internação Hospitalar (AIH) nos casos de atendimento das causas externas; 3) as Portarias SAS/MS 969 e 970/2002 que disponibilizam uma nova ficha de registro de entrada de pacientes no SUS, com a intenção de captar, com melhor qualidade, aqueles advindos dos acidentes e violências; assim como o Sistema de Informações em Saúde para Acidentes e Violências (Sisav).

Outros avanços podem ser observados a partir do ano 2001 também na área de Saúde Mental, que passou a discutir a inserção do atendimento às mulheres, crianças e adolescentes em situação de violência nos Centros de Apoio Psicossocial (Caps); no campo da Saúde do Adolescente e do Jovem, apoiando atividades de protagonismo juvenil como prevenção das violências; na área de Saúde do Idoso e do Portador de Deficiência que recém-começa a inserir a temática da violência em suas linhas de atuação. Em 2004, a Portaria GM/MS n. 2.406 disseminou a notificação compulsória da violência contra a mulher, de acordo com a Lei 10.778/2003 que estabelece essa forma de registro, Em 2005, o Ministério da Saúde lançou várias normas técnicas como as que tratam sobre atendimento aos agravos decorrentes da violência sexual; sobre a anticon- 
cepção de emergência nos casos de violência sexual contra mulheres e adolescentes e sobre a atenção humanizada às situações da interrupção da gravidez prevista em lei. Mais recentemente em 2006, lançou a 'matriz pedagógica' para formação de Redes de Atenção Integral para Mulheres e Adolescentes em situação de violência doméstica e sexual.

Todos os passos citados são importantes para a legitimação da política do setor, embora não sejam suficientes, pois podem redundar apenas em formas institucionalizadas de tratar o problema, confinando-o nos tentáculos da burocracia, em lugar de torná-lo uma questão de debate público. Essa nota é fundamental, principalmente porque os recursos adscritos para realização do Plano Nacional de Redução de Acidentes e Violência são irrisórios.

É relevante dizer que existe um grande número de experiências de prevenção da violência ocorrendo em todo o país. Algumas são intersetoriais, articulam ações do Estado e da sociedade civil e contam com o apoio das universidades. Apenas como exemplo, algumas intervenções intersetoriais, em que a cidadania e o cuidado com os jovens são os focos, já mostram impacto na diminuição das taxas de homicídio em nível local, como é o caso das experiências em Diadema, São Paulo, e em Belo Horizonte. No âmbito dos acidentes e violências no trânsito que matam quase 30.000 brasileiros por ano, as atividades com múltiplos focos e parceiros também evidenciam resultados positivos em alguns municípios, como é o caso de Recife, Curitiba, São Paulo, Belo Horizonte e Goiânia e Brasília. 


\section{$7 \mid \begin{aligned} & \text { MoRbi-MoRtalidade POR ViolênCias E } \\ & \text { Acidentes }\end{aligned}$}

O Brasil ocupa hoje o quarto lugar no ranking da violência na América Latina, depois de Colômbia, El Salvador e Venezuela. A violência e os acidentes que afetam a saúde dos brasileiros são responsáveis pela segunda causa de mortalidade geral e é a primeira causa nas amplas faixas etárias de 5 a 49 anos. Nos casos que exigem internação, a violência e os acidentes estão no sexto lugar de importância.

Como lembra um dos importantes documentos da Opas, escrito em 1994, a que já fiz referência, a violência, pelo número de vítimas e pela magnitude de seqüelas orgânicas e emocionais que produz, adquiriu um caráter endêmico na região das Américas e se converteu num problema de saúde pública em muitos países. O setor saúde constitui a encruzilhada para onde convergem todos os corolários da violência, pela pressão que exercem suas vítimas sobre os serviços de urgência, atenção especializada, reabilitação física, psicológica e assistência social.

\section{Alguns dAdOS EPIdemiológicos SOBRE VIOLÊNCIA}

Utilizando o termo 'causas externas' que corresponde à classificação das violências e acidentes, como já mencionado, o Ministério da Saúde registrou 1.118.651 mortes de brasileiros de 1991 a 2000. Dessas, 369.068 pessoas foram a óbito por homicídio; 62.480 , por suicídio e 309.212 por acidentes e violências 
no trânsito e nos transportes. As taxas de morte por causas externas tiveram forte incremento a partir da década de 1980, que, como mencionado anteriormente, inaugurou a época da democratização no país. Nesse período aumentaram as taxas de homicídios e de suicídio, e regrediram levemente as de acidentes de trânsito e de transporte. Cerca de $84 \%$ de toda a mortalidade por acidentes e violências em 2000, equivalente à perda de 99.474 pessoas, ocorreu na população masculina cujas taxas agregadas são de 119,0/100.000 habitantes. No grupo feminino, morreram 18.810 vítimas, numa proporção de 15,9\% e 21,8/100.000 habitantes. Nos primeiros cinco anos da primeira década do século XXI essa situação pouco mudou, havendo uma pequena oscilação nas taxas de homicídios.

A subcausa de morte que mais impressiona quando se observa o panorama da violência no Brasil são as agressões com morte. Nos últimos vinte anos, os homicídios tiveram crescimento proporcional de mais de $200 \%$ : passaram de 13.601 , em 1980, para 45.343, em 2000. O mais elevado incremento do fenômeno se deu na década de 1980. Na década seguinte, o número de mortos continuou alto e se elevando, embora com menos intensidade: de 1991 para 2000 a diferença foi de 47\%. Em 2000, os homicídios corresponderam a 38,3\% do total das mortes por causas externas no Brasil, confirmando-se tendência de acirramento. Em 1991, 50,3\% (15.460) deles ocorreram por armas de fogo; no ano 2000 esse percentual subiu para 68\%, correspondendo ao óbito de 30.855 pessoas. A maior parte das vítimas de mortes e dos traumatizados é constituída por homens, com taxas de 44/100.000, comparadas com as de 3,9/100.000 para mulheres, numa razão de 12/1. Ou seja, a vitimização da violência que mata é, eminentemente, masculina. 
Cerca de $70 \%$ de todos os homicídios ocorreram, nesses últimos vinte anos, nas faixas etárias de 10 a 39 anos, mais de $83 \%$ deles cometidos contra jovens do sexo masculino, em sua maioria, pobres e vivendo nas periferias das grandes cidades.

As lesões e lesões e traumas provenientes de acidentes e violências hoje ocupam o sexto lugar no conjunto das internações hospitalares. O custo médio de tratamento de pessoas feridas, traumatizadas ou lesionadas por acidentes e violências está bem acima do que corresponde ao custo médio das internações em geral. 



\section{Quadro Interpretativo da Violência 8 I sob a Ótica do Setor Saúde}

A visão do setor saúde sobre o tema da violência tem duas vertentes: uma explicativa, partindo de uma reflexão filosófica e teórica; outra operacional que se fundamenta na constatação nos transtornos biológicos, emocionais e físicos que sua dinâmica provoca no bem-estar e na qualidade de vida das pessoas.

Entre as instituições nacionais e internacionais há, cada vez mais, um consenso em torno do que o médico sanitarista Saul Franco Agudelo (1990: 6) vem repetindo em vários de seus estudos: "a violência representa um risco para a realização do processo vital humano: ameaça a vida, altera a saúde, produz enfermidade e provoca a morte como realidade ou como possibilidade próxima". Ou seja, o setor saúde e seus profissionais não vislumbram positividade nas manifestações da violência. Ao contrário, consideram-nas negativas para a sociedade, para os indivíduos e para o próprio setor.

A OMS, em recente relatório sobre o assunto, define a violência como "o uso da força física ou do poder, real ou em ameaça, contra si próprio, contra outra pessoa, ou contra um grupo ou uma comunidade, que resulte ou tenha qualquer possibilidade de resultar em lesão, morte, dano psicológico, deficiência de desenvolvimento ou privação" (OMS, 2002: 5).

Quando a OMS divulgou essa definição em 2002, o Ministério da Saúde do Brasil já havia publicado, oficialmente (Portaria MS/GM n. 737 de 16/5/2001) seu documento Política Nacional 
de Redução da Morbi-mortalidade por Acidentes e Violências, introduzindo um conceito mais ou menos semelhante ao da OMS: "consideram-se como violências, ações realizadas por indivíduos, grupos, classes, nações que ocasionam danos físicos, emocionais e espirituais a si próprios e aos outros" (Brasil, 2001: 7).

Nos dois textos está implícito o caráter operacional das definições. No entanto, ambos ressaltam o sentido de intencionalidade da violência, o que é um tema filosófico essencial. A questão da intencionalidade situa a violência no âmbito eminentemente humano, pois só os humanos, antropológica e convencionalmente, possuem intencionalidade em seus atos ou omissões. Ressaltando o seu lugar nas relações sociais, desde o nível subjetivo, a microesfera da família até o âmbito macrossocial e global, a idéia de intencionalidade mostra que a violência é um fenômeno sobre o qual existe responsabilidade dos sujeitos individuais e coletivos, uma vez que as ações violentas se realizam por meio das pessoas dentro de sua cultura. Essa historicidade cultural fundada na necessidade (as determinações) e na liberdade (o protagonismo) nos dá a esperança de que a violência pode e deve ser analisada, compreendida, objeto de intervenção direta e indireta e, ainda, superada.

Os documentos mencionam também a negligência e a omissão como formas de violência. Esse é um passo fundamental para que se desnaturalizem processos estruturais e atitudes de poder que se expressam em ausência de proteção e cuidados. E, por isso, perenizam injustiças de todas as ordens, seja no nível das relações primárias, seja nos âmbitos econômicos, políticos, culturais que assim impedem pessoas e grupos de crescerem e de se desenvolverem.

O Relatório da OMS (2002) não trata dos acidentes que, na CID estão categorizados junto com as violências na rubrica 
'causas externas'. Aí se incluem os agravos e mortes auto-infligidos ou heteroinfligidos. Preferi, neste livro, falar também dos acidentes, pois o Ministério da Saúde os considera de forma associada com as violências, definindo-os como "evento não intencional e evitável, causador de mortes ou lesões físicas e emocionais, no ambiente doméstico ou nos outros ambientes sociais como o do trabalho, o do trânsito, o da escola, o do esporte e do lazer" (Brasil, 2001: 8).

Quando se decide falar dos acidentes é porque, na prática e quase sempre, existe associação entre eles e outras formas de violência. Freqüentemente, não se tem condições de dizer, por exemplo, que a queda de uma pessoa idosa dentro de um ônibus foi mero acidente ou se ela ocorreu por falta de atenção do motorista ao arrancar bruscamente a viatura. Igualmente é difícil dizer que uma criança que se envenenou, ingerindo produto de limpeza doméstica, tenha morrido por acidente ou por negligência dos familiares que deveriam cuidar dela e, no mínimo, colocar os recipientes num lugar seguro. Ainda, freqüentes mortes no trânsito poderiam ser consideradas suicídios, pelas formas de autodestruição como ocorreram; ou como homicídio, pelas circunstâncias sobejamente conhecidas como se processaram. Por exemplo, alta velocidade, abuso de álcool e sono são fatores 'preveníveis' e que têm elevadíssima associação com mortes e lesões ocorridas em acidentes de transporte. Alguém que acidenta pessoas no trânsito por dirigir embriagado, não tem intencionalidade e vontade própria quando abusa da bebida alcoólica? Um operário que cai de um andaime inseguro: a negligência da empresa ou dele próprio, poderá ser considerada sem intencionalidade? Diante das dificuldades para se estabelecer com precisão o 
caráter de intencionalidade, tanto dos eventos violentos quanto dos acidentes, entendo que sua classificação comporta sempre um grau de imprecisão.

Nos estudos científicos da área da saúde há pelo menos três correntes que buscam explicar a violência. $\mathrm{Na}$ primeira estão os autores que sustentam a idéia de que ela é resultante de necessidades biológicas; na segunda, aqueles que a determinam a partir, exclusivamente, do arbítrio dos sujeitos, como se os resultados socialmente visíveis dependessem da soma dos comportamentos individuais, ou se a violência fosse resultante de doença mental, ou ainda, estivesse vinculada a determinadas concepções morais e religiosas. $\mathrm{Na}$ terceira, estão os autores que consideram a violência como um fenômeno eminentemente social em intrincada relação com predisposições genéticas e traços de personalidade.

No caso das explicações biológicas, são vários os autores que analisam as propensões dos indivíduos à agressão ou ao crime. Muitos estudos consideram que o comportamento violento é uma resultante dos condicionamentos biogenéticos, sendo, portanto, um fenômeno inerente à natureza humana. Em diferentes textos sociológicos e da área da saúde, no entanto, se fazem sérias críticas à ênfase excessiva na concepção biologicista. Esse tema foi particularmente tratado pela Unesco num seminário em Paris no ano de 1980, e suas importantes reflexões estão registradas no livro La Violencia y sus Causas, em que dois autores, Laborit (1981) e Klineberg (1981) discorreram sobre o assunto.

Laborit desenvolveu a idéia de que nos sistemas hipercomplexos não se encontram causas de uma ação, pois a causalidade já não pode ser concebida de modo linear (causa-efeito) de acordo com a interpretação do determinismo do final do século XIX. Hoje deve ser considerada a íntima relação entre o que é inato e 
o que é aprendido socialmente. $\mathrm{O}$ autor trabalha sobre dois temas centrais: as bases neurofisiológicas e bioquímicas dos comportamentos fundamentais e a significação funcional dos centros nervosos superiores. Trata de forma particular a questão da 'agressividade predatória' que é inata e motivada pela fome, e da 'agressividade de competição'. Esta última se apoiaria na aprendizagem da gratificação, na busca de dominação e no estabelecimento de hierarquias, como um comportamento adquirido, vinculado ao acesso a objetos gratificantes. E, igualmente, analisa a 'agressividade defensiva' como comportamento inato, provocado por um estímulo doloroso, que chegaria a ser comportamento adquirido quando é recompensado ou gera punição. No final de seu estudo, conclui Laborit (1981: 66):

Com exceção da agressividade predatória que, caberia perguntar se deveria continuar incluída no marco dos comportamentos agressivos próprios do ser humano, os demais tipos de comportamento agressivo são, ou o resultado de aprendizagem, e, portanto, suscetíveis de serem transformados pela sociocultura, ou então constituem uma resposta elementar a um estímulo doloroso.

A partir da psicologia social, Klineberg discute a hipótese da teoria da frustração-agressão como explicação da violência. Resumindo seu pensamento, diz o autor que vários especialistas concordam que a frustração aumenta a probabilidade do comportamento violento, mas essa não é uma conclusão simples, pois, são muitos os fatores que também contribuem para isso. Os estudos sobre participação em conflitos ou sobre comportamentos violentos mostram que os que assim agem possuem um certo grau de controle sobre o próprio destino. E, ao contrário, a sensação de impotência costuma gerar apatia e submissão. 
Em seguida Klineberg evidencia outras categorias (que em geral combinam a presença de fatores sociais e biológicos) que contribuem para diferenciações, na probabilidade de que ocorram ações de violência individual e coletiva: idade e sexo; universalmente os homens cometem mais violência que as mulheres e os jovens mais que outros grupos etários. O autor não deixa de chamar atenção para o fato de que fatores culturais desempenham papel importante na configuração do problema: o machismo e a relação intermachos, por exemplo. Aponta, também, a questão étnica, racial e de classe, para dizer que nada comprova que os negros são geneticamente mais violentos que os brancos e que os pobres, mais que os ricos. O fator de dominação política, econômica e social é muito mais explicativo que o caráter biológico das diferenças, segundo Klineberg. A questão da 'aglomeração demográfica' é também lembrada e comparada às situações, em laboratório, de ajuntamento excessivo de animais, gerando a destruição entre eles. Mas o autor fala do risco das extrapolações que têm sido feitas em relação à explosão populacional, pois, historicamente, não há provas de que elas geram violência.

Klineberg, finalmente, comenta um grande estudo realizado por Wolfang e Ferracuti (1967), ressalvando que se trata de uma pesquisa antiga. Os mencionados estudiosos aplicaram teste de personalidade em sujeitos que cometeram homicídios. Segundos os próprios autores, os resultados não foram conclusivos. No entanto, há algumas características que aparecem com regularidade nos estudos sobre a personalidade de criminosos: o egocentrismo, a falta de controle emocional, a propensão a ser explosivo, a imaturidade e a incapacidade de estabelecer contatos sociais duradouros, a pouca sensibilidade para com os ou- 
tros e a forte necessidade de gratificação imediata de seus impulsos. Nesse agrupamento de causas associativas se apresenta uma combinação de características de personalidade, de formação e de educação.

$\mathrm{O}$ estudo feito por Wolfang e Ferracuti encontra eco em recente pesquisa empírica realizada pela médica e epidemiologista Simone Gonçalves de Assis (1999), que analisa os aspectos bio-psicossociais e as mais sutis diferenças entre jovens infratores e seus irmãos não infratores de duas cidades brasileiras: Rio de Janeiro e Recife. A autora discute seus dados com as teorias clássicas que ora privilegiam o social, ora os componentes individuais na origem da personalidade delinqüente. E conclui que:

os principais fatores de risco associados à situação de infrator são: consumo de drogas, participação em círculo de amigos que aprovam a criminalidade, tipos de lazer violento, baixa autoestima, falta de reconhecimento de limites entre certo e errado, fraco vínculo afetivo com a família e com a escola, e sofrer ou ter sofrido violência por parte dos pais. (Assis, 1999: 201)

A pesquisadora acrescenta que há uma rede social de antecedentes que propiciam uma cultura de violência, como a existência ou não de pessoas com comportamento delinqüente na família, violência entre os pais e irmãos e violência na comunidade.

$O$ estudo de Assis revela importantes características individuais de personalidade dos infratores: comportamento imediatista e nervoso, valente e aventureiro; rebeldia em relação aos problemas da vida; dificuldade de controlar a agressividade; dificuldade de empatia com o outro; baixa auto-estima. No entanto, ela tece comentários sobre o que considera "uma linha tênue" relativa às dificuldades das condições e do estilo de vida, separando os irmãos infratores e os não infratores, mostrando 
que o ambiente em que esses jovens são criados é muito pouco propício para que resistam aos apelos dos grupos criminosos. Em contrapartida, do ponto de vista biológico, a investigação evidencia o quanto é problemático demonstrar diferenças herdadas, uma vez que se trata de pesquisa envolvendo irmãos.

Um biólogo brasileiro, Flores (2002), recentemente retomou o assunto da determinação biológica do comportamento violento, à luz dos avanços da genética. O autor questiona o repúdio dos pesquisadores da área social e de saúde coletiva em reconhecer as teorias biológicas como explicação para a violência. Flores parte do princípio de que a contribuição da biologia, da genética do comportamento e da psicologia evolutiva não tem sido bem compreendida pelos cientistas sociais que analisam o fenômeno. Diz ele:

Genes não são a matéria bruta da evolução; comportamentos, por serem fenótipos, o são. Comportamentos selecionam genes e não o contrário. É um equívoco assumir que a teoria evolutiva enfatiza o controle biológico do comportamento. Ao contrário, ela explica como os fatores ambientais e culturais moldam, não só a evolução do cérebro, mas também o seu desenvolvimento em cada indivíduo. (Flores, 2002: 198)

O biólogo relaciona a genética à criminalidade violenta pela mediação do conceito de 'transtorno de personalidade antisocial'. Esse tipo de transtorno para ele seria um problema crônico, que tem início na segunda década da vida, sendo caracterizado, em sua versão mais profunda, por ausência de culpa, vergonha, remorso, pobreza de relações afetivas, incapacidade de aprender com a experiência e insensibilidade social. $\mathrm{O}$ autor fundamenta seu pensamento num trabalho de campo com 560 jovens gaúchos com mais de 14 anos, vivendo em regime de 
privação da liberdade, para os quais, em $40 \%$ dos casos, houve diagnóstico de problema mental. Esse índice atingiu 90\% dos que tinham 19 e 20 anos.

O trabalho de Flores tem o mérito de reabrir a discussão sobre a presença dos fatores biológicos na construção da violência em outro patamar: a biologia sendo reconfigurada e culturalizada pelo comportamento e pelo ambiente social. Afirma o biólogo que Raine e Liu (1998) identificaram uma combinação explosiva para a emergência de comportamentos violentos quando se reúnem: fragilidades biológicas, estimadas pela presença de problemas neurológicos, atraso no desenvolvimento psicomotor e complicações de parto; ambiente familiar inadequado e história familiar positiva para a criminalidade.

As teorias biologicistas, no entanto, não podem ser consideradas conclusivas por si sós, pois, se assim fossem valorizadas, correríamos o risco do reducionismo unidisciplinar e político. Todo o conhecimento desenvolvido pela sociologia e pela psicologia criminal demonstra serem as pessoas das classes subalternas muito mais facilmente 'apreendidas em delitos', do que as das classes dominantes: seriam esses fatores ambientais e culturais (ou seja, ter nascido pobre e em ambiente pobre, nas periferias urbanas) que moldariam, não só a evolução do cérebro, mas também o desenvolvimento dos jovens que entram no mercado da violência? Sobre o assunto diz o biólogo Laborit (1981: 62-3):

Essa agressividade fundamental, que permite aos dominantes conquistarem e conservarem sua posição de domínio, está tão perfeitamente ritualizada e institucionalizada que deixou de ser manifesta. Ela adotou o aspecto do direito, da justiça e 
da ausência de agressividade, a ponto de se permitir, freqüentemente, profissão de fé humanista, de piedade, de mansidão, ao mesmo tempo em que estigmatiza as explosões brutais de violência dos dominados.

Considero, portanto, um vício do pensamento e um viés de classe acreditar que os pobres são biologicamente mais propensos ao crime. O fato de mais de $90 \%$ dos apenados brasileiros serem pessoas das camadas populares e de baixa escolaridade não pode ser um argumento para afirmar que todos estão lá por algum distúrbio que afete sua saúde mental. Ou são mais facilmente colhidos cometendo infrações, ou as condições objetivas de vida ou ainda escolhas pessoais pela transgressão (o que não quer dizer propensão biológica) os levaram ao lugar onde estão.

Sobre o tema, é esclarecedor um estudo realizado pelo psicólogo social Venthecourt (1990), no qual analisa uma rebelião social na Venezuela, provocada por aumento do custo de vida e dos preços dos transportes públicos. No evento houve violentos e massivos assaltos aos supermercados e depredação dos veículos na cidade de Caracas. $\mathrm{O}$ autor comenta que esse problema deveria ser estudado não por psicólogos que encontrassem associação entre revolta e problemas mentais, mas, sim, por sociólogos capazes de analisar a implicação da questão social para a subjetividade. Afirma Venthencourt que a maioria dos delinqüentes de seu país assim o é, não por problemas psicopatológicos, mas por razões sociais, pela falta mais cabal de oportunidade de se constituir como sujeito e cidadão. $\mathrm{O}$ autor faz uma distinção entre o baixo percentual de pessoas com psicopatologias que levam ao crime e a maioria de infratores criados pelas condições adversas da vida. No entanto, afirma, essas condições adversas acabam gerando uma cultura de violência, posição que se coaduna com as perspectivas traçadas por Flores. 
Lembrando que não é apenas a criminalidade e a delinqüência que configuram a violência, ressalto que seria difícil explicar uma série de manifestações que vitimam crianças com argumentos biológicos. Todos sabemos que o pátrio poder, no primeiro caso; a visão patriarcal que alimenta o machismo, no segundo; e o 'desinvestimento' e rechaço social no caso dos idosos, por razões políticas e micropolíticas, são muito mais fortes do que as diferenciações biológicas de idade, de sexo e de decrepitude.

Em resumo, todos os exemplos citados chamam atenção para a combinação de aspectos biológicos e sociais na construção de tipos de personalidade e subjetividades, inclusive as que se consideram violentas. Porém, o locus de expressão dessas subjetividades é o contexto histórico-social, cujas particularidades biológicas encontram as idiossincrasias de cada um e se redefinem nas condições emocionais e socioculturais em que as pessoas crescem e se desenvolvem.

A reflexão desenvolvida até aqui não torna a tarefa dos profissionais de saúde mais fácil. Ao contrário, mostra a necessidade não só de trabalharem com modelos epidemiológicos, mas também de incluírem a compreensão cada vez mais específica dos fatores e dos contextos na abordagem dos comportamentos, das ações e dos processos violentos. Igualmente, torna-se fundamental aprofundar a importância e o papel da subjetividade e das determinações sociais nas escolhas de possibilidades, por menores que sejam as opções dos indivíduos. As explicações biológicas, em seu sentido mais restrito, consideradas as determinantes dos comportamentos violentos, só podem ser aceitas nos casos patológicos, nos quais os indivíduos devem ser avaliados com instrumentos compreensivos específicos. 
Do ponto de vista operacional, o setor saúde trabalha com classificações, tipologias e estratégias de abordagem.

\section{TIPOLOGIA DA VIOLÊNCIA}

Procurarei acompanhar a tipologia proposta para classificação da violência que acompanha o Relatório Mundial da OMS (2002) e categoriza o fenômeno a partir de suas manifestações empíricas: violência dirigida da pessoa contra si mesma (autoinfligida), violência interpessoal e violência coletiva.

\section{- Violências auto-infligidas}

Em violências auto-infligidas incluem-se os comportamentos suicidas e os auto-abusos. No primeiro caso, a tipologia contempla suicídio, ideação suicida e tentativas de suicídio. O conceito de auto-abuso nomeia as agressões a si próprio e as automutilações.

\section{- Violências interpessoais}

As violências interpessoais são classificadas em dois âmbitos: o intrafamiliar e o comunitário.

Por violência intrafamiliar entende-se a que ocorre entre os parceiros íntimos e entre os membros da família, principalmente no ambiente da casa, mas não unicamente. Inclui as várias formas de agressão contra crianças, contra a mulher ou o homem e contra os idosos no âmbito doméstico. Considera-se que a violência intrafamiliar é, em geral, uma forma de comunicação entre as pessoas e, quando numa família se detecta um tipo de abuso, com freqüência, ali existe uma inter-relação que expressa várias formas de violência.

A violência comunitária é definida como aquela que ocorre no ambiente social em geral, entre conhecidos e desconhecidos. 
Consideram-se suas várias expressões, como violência juvenil, agressões físicas, estupros, ataques sexuais e, inclusive, a violência institucional que acontece, por exemplo, em escolas, locais de trabalho, prisões e asilos.

\section{- Violências coletivas}

Por violências coletivas entendem-se os atos violentos que acontecem nos âmbitos macrossociais, políticos e econômicos e caracterizam a dominação de grupos e do Estado. Nessa categoria, do ponto de vista social, incluem-se os crimes cometidos por grupos organizados, atos terroristas, crimes de multidões. No campo político, a violência coletiva se expressa nas guerras e nos processos de aniquilamento de determinados povos e nações por outros. A classificação de violência coletiva contempla também ataques econômicos entre grupos e nações, geralmente motivados por intenções e interesses de dominação.

À classificação criada pelo Relatório da OMS (2002), acrescento um tipo de violência a que denomino 'estrutural'. Essa categoria se refere aos processos sociais, políticos e econômicos que reproduzem e 'cronificam' a fome, a miséria e as desigualdades sociais, de gênero, de etnia e mantêm o domínio adultocêntrico sobre crianças e adolescentes. Difícil de ser quantificada, pois aparentemente ocorre sem a consciência explícita dos sujeitos, a violência estrutural se perpetua nos micro e macroprocessos sócio-históricos, se repete e se naturaliza na cultura e é responsável por privilégios e formas de dominação. A maioria dos tipos de violência citados anteriormente tem sua base na violência estrutural. 


\section{NATUREZA DA VIOLÊNCIA}

Geralmente a natureza dos atos violentos pode ser classificada em quatro modalidades de expressão, também denominadas abusos ou maus-tratos: física, psicológica, sexual e a que envolve abandono, negligência ou privação de cuidados.

- O termo abuso físico significa o uso da força para produzir injúrias, feridas, dor ou incapacidade em outrem.

- A categoria abuso psicológico nomeia agressões verbais ou gestuais com o objetivo de aterrorizar, rejeitar, humilhar a vítima, restringir a liberdade ou ainda, isolá-la do convívio social.

- A classificação abuso sexual diz respeito ao ato ou ao jogo sexual que ocorre nas relações hetero ou homossexual e visa a estimular a vítima ou utilizá-la para obter excitação sexual e práticas eróticas, pornográficas e sexuais impostas por meio de aliciamento, violência física ou ameaças.

- Negligência ou abandono inclui a ausência, a recusa ou a deserção de cuidados necessários a alguém que deveria receber atenção e cuidados.

Todas as tipologias descritas comportam as classificações distribuídas no que aqui considero 'natureza da violência'. 


\section{9 \begin{tabular}{l|l} 
Expressões Culturais de Violência e \\
Relação com a Saúde
\end{tabular}}

\section{VIOLÊNCIA CONTRA CRIANÇAS E JOVENS}

No caso brasileiro, a violência que atinge crianças e adolescentes tem muitas faces e aqui abordo suas principais manifestações: estrutural, intra-familiar, institucional e delinqüencial.

\section{- Estrutural}

É aquela que incide sobre a condição de vida das crianças e adolescentes, a partir de decisões histórico-econômicas e sociais, tornando vulneráveis suas possibilidades de crescimento e desenvolvimento. Por ter um caráter de perenidade e se apresentar sem a intervenção imediata dos indivíduos, essa forma de violência aparece naturalizada, como se não houvesse nela a intervenção dos que detêm o poder e a riqueza. A intervenção específica do setor saúde, nesse sentido, deve ser feita para reduzir e eliminar as desigualdades em saúde, ampliar o acesso e a qualidade da atenção. Porém, no âmbito da cidadania, os profissionais deveriam se engajar nos processos políticos de transformação social.

A expressão mais cabal desse tipo de violência é o fato de, dentre as 60 mil crianças e adolescentes brasileiros de 0 a 17 anos (Censo de 2000 do IBGE), 20 milhões (34,8\%) se encontrarem em situação de pobreza, vivendo em famílias com renda mensal de até meio salário mínimo per capita. Em regiões mais pobres, 
como o Nordeste, o percentual chega a 58,8\%, evidenciando a gravidade e a persistência das precárias condições de vida em geral e, sobretudo, da infância e juventude.

A violência estrutural tem várias formas-limite de manifestação. Três maiores expressões de vulnerabilidade são a existência de meninos e meninas vivendo ou trabalhando nas ruas; de meninos e meninas trabalhando para sobreviver; da vida de meninos e meninas dentro das instituições de privação de liberdade.

Os vários estudos sobre o fenômeno 'meninos e meninas de rua’ revelam que as principais causas dessa situação é a falta de condições das famílias de mantê-los e os conflitos e violências do núcleo familiar. No entanto, nas ruas eles convivem com ameaças às suas próprias vidas, potencial indução ao crime, maustratos praticados por policiais ou por outros, exploração por comerciantes, seguranças, além de serem estigmatizados como 'futuros bandidos'.

Em relação ao trabalho infantil, desde 1998, a lei brasileira permite que crianças, a partir de 14 anos, trabalhem apenas como aprendizes e, acima dos 16 anos, tenham vínculos formais. Mas a Constituição determina que menores de 18 anos não podem trabalhar em horários noturnos (das $22 \mathrm{~h}$ até $5 \mathrm{~h}$ da manhã) nem em atividades consideradas perigosas e insalubres. No entanto, o fenômeno social denominado 'trabalho infantil' é hoje uma das formas de expressão da violência estrutural no país.

Segundo dados do IBGE, na Pesquisa Nacional por Amostra de Domicílios (Pnad) de 2001, havia no Brasil 5.482.515 crianças entre 5 e 17 anos trabalhando. Dessas 2.231.974 (40\%) tinham menos de 14 anos e a maioria (3.570.216) eram meninos. Dos trabalhadores infantis até 13 anos, grande parte estava empregada na área rural e em atividades agrícolas. De 14 anos para 
cima aumentavam as atividades no setor de serviços e indústrias. No campo, 77\% do trabalho infantil não é remunerado. Nas áreas urbanas, 16\% das crianças e adolescentes realizam atividades domésticas não remuneradas.

As principais ocupações das crianças e adolescentes que trabalham no campo são atividades agrícolas. Nas áreas urbanas, têm empregos como balconistas, ajudantes de pedreiro e em restaurantes, comércio ambulante, oficinas de carro e serviços domésticos como babás, diaristas, atendentes e cozinheiras. As atividades informais urbanas ocorrem em maiores proporções no Sudeste e Centro-Oeste, onde as crianças vendem frutas, balas e flores nos sinais de trânsito, engraxam sapatos, lavam pratos em restaurantes, guardam carros, dentre outras atividades.

Em todos os estados brasileiros, o IBGE, na Pnad de 2001, ainda encontrou trabalho infantil. $\mathrm{O}$ que tem a menor proporção é o Distrito Federal com 4\%, ao passo que o Maranhão ocupa o primeiro lugar com $22 \%$ de suas crianças trabalhando. Não é mera coincidência o fato de que nesse estado estejam concentrados os mais elevados índices de desnutrição infantil, de exportação de mão-de-obra escrava e de desigualdades sociais no país.

Cerca de $88 \%$ das crianças até 10 anos, que trabalhavam em 1998, não recebiam qualquer rendimento. Aos 17 anos, a proporção das que não recebiam remuneração descia para 40\%. Ainda que esse quadro tenha melhorado em 2001, as tendências não são de fácil reversão. $O$ trabalho infantil tem um efeito muito perverso no desenvolvimento e crescimento das crianças e adolescentes. Aos 17 anos, a defasagem idade-série dos que trabalham é de 3,7 anos e a dos que não trabalham, 2,7 anos. Mais grave que a defasagem citada é o fato de que, aos 17 anos, cerca de $40 \%$ daqueles que trabalhavam estivessem fora da escola, em 
comparação com os $32 \%$ dos que não trabalham. Em ambos os casos, esse mau desempenho escolar geral, que se agrava no caso de crianças e jovens trabalhadores, é preocupante para a sociedade brasileira, pois denota problemas sérios de qualidade do sistema educacional.

Além do significado negativo do trabalho infantil tanto para o país como para as pessoas, esse quadro tem mais alguns ingredientes de crueldade. Nas áreas urbanas, o trabalho de crianças nas gangues de tráfico de drogas foi atividade incluída pela Organização Internacional do Trabalho (OIT) entre as formas de trabalho infantil intoleráveis, junto com a exploração sexual e sua escravização. No campo, algumas fazem parte das situações de escravidão, junto com os pais. No que concerne a problemas de insalubridade e periculosidade, ambas proibidas pela Constituição, embora as grandes empresas garantam o cumprimento da legislação sobre o assunto, as terceirizações de atividades para o âmbito familiar, por exemplo, como acontece na colagem de solas de sapatos no setor de produção de calçados, perpetua a ilegalidade. Além disso, nos canaviais, na cultura do sisal ou nas plantações de fumo, crianças e adolescentes estão expostos ao manejo de ferramentas cortantes, ao carregamento de fardos pesados, ao uso contínuo de agrotóxicos, além de, freqüentemente, terem longas jornadas de trabalho.

Os dados citados anteriormente, quando comparados com os dos últimos dez anos, indicam significativa diminuição $(35,0 \%)$ na expansão do emprego da mão-de-obra infantil, evidenciandose um esforço nacional para superar o problema. De 1992 a 2001, quase 3 milhões de crianças deixaram de trabalhar; em 1992, eram 9,7 milhões. Essa queda é fruto de fortes investimentos governamentais, de ONGs, e de organizações internacionais e da imprensa, 
para que sejam cumpridas convenções de Direitos Humanos e o ECA e para que sejam criados mecanismos para transformar a situação. No entanto, especialistas concordam que, da mesma forma que no trabalho escravo, não bastam leis, diretrizes e coibições. A origem secular do trabalho infantil no mundo e, particularmente no Brasil, está, em primeiro lugar, na pobreza, na miséria e na má distribuição de renda. Em segundo lugar, vem o peso da cultura rural, sobretudo no sul do país, onde, apesar de as condições sociais no campo serem bem melhores que as do Nordeste. $\mathrm{Na}$ região Sul, quase metade das crianças e adolescentes, cujos pais trabalham em atividades agrícolas, também trabalha, em proporções mais elevadas do que as de todas as outras regiões.

A institucionalização é utilizada como meio de se contrapor ao abandono ou por motivos ditos 'ressocializadores'. A história brasileira mostra a total ineficiência, ineficácia e incompetência das instituições de internação, cujo objetivo é promover a recuperação e crescimento infantil e juvenil. Elas próprias são produtoras de violência física, emocional e de negligência, o que acontece por múltiplas razões: forma burocrática de organização e de atendimento, cujo caráter é impessoal e despersonalizante, criando impossibilidade de vínculos e laços significativos; fechamento para o mundo exterior e monotonia do cotidiano baseado na disciplina e não nas formas de desenvolvimento dos sujeitos, gerando pobreza das relações pessoais. Não há prioridade dos governos na formação dos jovens que vivem reclusos por algum tempo nas instituições e, mesmo depois do ECA, muitas delas continuam a funcionar como verdadeiras prisões.

Ora, as três situações-limite que persistem no país como verdadeiras pontas do iceberg da violência estrutural são a antítese da proteção integral preconizada pelo ECA. 


\section{- Violência intrafamiliar}

As pesquisas sobre violência intrafamiliar, isto é, aquela que ocorre no lar, têm mostrado que, geralmente, a violência é uma forma de comunicação e de relação interpessoal. Quando numa casa se observam maus-tratos e abusos contra algum de seus moradores, é quase certo que todos acabam sofrendo agressões, embora com diferenciações hierárquicas. Estudos têm mostrado que as crianças são as maiores vítimas, pois a raiva, os ressentimentos, as impaciências e emoções negativas dos outros membros as atingem como se elas fossem válvulas de escape. Por isso, alguns autores falam que a violência intrafamiliar contra crianças e adolescentes costuma ser funcional, provocando uma espécie de homeostase. Sua fragilidade física e de personalidade as torna alvos fáceis do poder dos adultos.

Levantamentos do IBGE revelam que cerca de $20 \%$ das crianças e adolescentes sofrem violência física e $80 \%$ dos agressores são seus próprios pais. Vários estudos reafirmam esses dados. Assis (1994), comenta em uma de suas pesquisas, que, num universo de 1.328 adolescentes de escolas públicas e particulares, encontrou a seguinte realidade: $75 \%$ dos entrevistados referiram os irmãos como autores de atos violentos; $40 \%$, a mãe e $45 \%$, o pai, confirmando a tese da comunicação violenta em determinadas famílias, afetando a todos os membros. A ocorrência de agressão severa foi mencionada por $40 \%$ dos adolescentes.

Do ponto de vista clínico, os agravos provocados por maustratos físicos são freqüentes na pele, nas mucosas, no esqueleto, no sistema nervoso central, no tórax e no abdome. As lesões cutâneo-mucosas podem ser devidas a golpes, queimaduras, arrancamento de dentes e de cabelos, mordidas e por armas brancas ou de fogo. Elas vão desde hiperemia, escoriações, equimoses e 
hematomas até queimaduras de terceiro grau. No esqueleto, as agressões físicas costumam provocar mutilações e fraturas dos ossos e dos membros em diferentes estágios de gravidade. No sistema nervoso central, a violência física é responsável por traumatismos crânio-encefálicos que podem ocasionar fraturas dos ossos do crânio ou hemorragias intracerebrais por causa de sacudidelas e impactos. Muitas crianças sofrem também lesões oculares e auditivas, levando à invalidez temporária ou permanente e até à morte.

Vários autores vêm associando (obviamente de forma não linear) punição física a delinqüência, por causa de sentimentos ambíguos, confusos ou vingativos que ela gera, como angústia, raiva, ansiedade, medo, terror, ódio e hostilidade.

A violência sexual é uma das formas de abuso freqüentes no ambiente familiar. Os estudos mostram que as principais vítimas são meninas, e os agressores são o pai, o padrasto, ou ainda, pessoas conhecidas e do relacionamento familiar com a vítima. Essa forma de abuso costuma ter como conseqüência a gravidez precoce de adolescentes e abortos clandestinos; o abandono do lar pelas meninas e meninos e o aumento do número de crianças vivendo nas ruas. Além disso, também tem impacto sobre a saúde das vítimas, tanto do ponto de vista físico como mental, exteriorizando-se a curto, médio e longo prazo. Do ponto de vista físico, os agravos devem ser observados em todas as áreas envolvidas nas práticas sexuais, como boca, mamas, genitais, região perineal, nádegas e ânus. As lesões podem se apresentar como hiperemia, edema, hematomas, escoriações, fissuras, rupturas, sangramentos, gravidez precoce e doenças sexualmente transmissíveis.

Do ponto de vista emocional, há uma variedade de sintomas associados, dependendo da idade, das condições psicológicas 
das vítimas, da sua história anterior, do grau de parentesco com o abusador e da freqüência e repetição do ato. Observa-se, em geral, que as vítimas têm mais dificuldade de aprendizagem, distúrbios de comportamento como dispersão, fobias e terror noturno, comportamentos autodestrutivos, isolamento social, atitudes erotizadas precoces com interesse por brincadeiras sexuais, dificuldade para fazer amizades, baixa auto-estima e depressão.

É difícil quantificar este fenômeno, porque a notificação é muito discrepante e só ocorre com a intervenção concreta de terceiros que podem ajudar a vítima a buscar atendimento ou a denunciar.

A violência psicológica ocorre quando os adultos sistematicamente depreciam as crianças, bloqueiam seus esforços de autoestima e as ameaçam de abandono e crueldade. Essa forma de relacionamento, também difícil de ser quantificada, provoca grandes prejuízos à formação da identidade, da subjetividade, gerando pessoas medrosas ou agressivas e que, dificilmente, aportarão à sociedade todo o potencial que poderiam desenvolver. Essa forma de abuso passa pela forma cultural com que pais e adultos concebem as crianças e os adolescentes, considerandoos sua posse exclusiva e acreditando que humilhá-los é a melhor forma de educar.

O abuso psicológico freqüentemente está associado a distúrbios do crescimento e do desenvolvimento psicomotor, intelectual e social. Um ambiente de dominação e humilhação pode potencializar sintomas de agressividade, passividade, hiperatividade, depressão e de baixa estima; ou ainda, aumentar, nos jovens, as dificuldades de lidar com a sexualidade.

As negligências representam omissão em relação à proteção integral. Elas se expressam na falta de provimento de alimentos, 
roupas, cuidados escolares e médicos e de outros cuidados necessários ao desenvolvimento e crescimento infantil e juvenil. A negligência costuma se apresentar em situações limítrofes entre pobreza e maus-tratos. Ou seja, uma vez que a negligência se define pela omissão de cuidados e de atendimento às necessidades das crianças, a reconhecida ausência de condições econômicas de famílias em situação de pobreza e miséria dificulta um julgamento mais preciso entre a prática abusiva e a impossibilidade de prover os requisitos para seu crescimento e desenvolvimento. No entanto, também nas classes média e alta, a ausência real e moral dos pais em relação ao diálogo, ao afeto e à atenção aos filhos é muito comum, tendo fortes repercussões no comportamento infantil e juvenil.

Do ponto de vista físico e afetivo, freqüentemente se encontram, nas crianças negligenciadas, lesões de pele por repetição da má higiene corporal, desnutrição, calendário vacinal desatualizado, tratamentos médicos inadequados. Por vezes, essas negligências levam à reincidência de internações, acidentes domésticos freqüentes, inadequação do nível de escolaridade à idade cronológica, absenteísmo da escola e omissão de atenção e de limites frente às várias situações do cotidiano.

\section{- Violência delinqüencial}

Sobretudo depois da promulgação do ECA, a opinião pública e a imprensa nacional se esmeram em colocar um foco de luz especial sobre a delinqüência juvenil. No último censo do IBGE sobre o tema realizado em 1997, havia 20.352 adolescentes e jovens de 12 a 20 anos cumprindo medidas socioeducativas (internamento, semi-internamento, escolas especiais, serviços à comunidade) em todo o país. Num total de 4.245 internados, 
havia 12 meninos para uma menina. Numa sociedade com tantas desigualdades como a brasileira, o fato precisa ser analisado de forma associada à violência estrutural e à questão de classe, pois quase a totalidade dos que estão em regime de medida socioeducativa é composta por meninos e meninas pobres. Nesses casos, combina-se a situação de precariedade social com os preconceitos e as dificuldades, por parte dos jovens, de pensar um projeto de vida, fora das condições estruturais desfavoráveis. Sobretudo nas grandes cidades, muitos ficam entre a escolha de inserção no mercado varejista de drogas, no subemprego ou nos empregos desqualificados, pois é também aos mais pobres que faltam estudos formais e qualificação profissional.

Um ponto importante a ser observado é que a magnitude da delinqüência infanto-juvenil é muito menor do que a reação da sociedade contra ela, o que também é um fenômeno universal e histórico. Estudo de Assis (1999) revela que no ano de 1994 havia 134 infratores jovens de 12-17 anos para cada 100.000 habitantes no Rio de Janeiro, enquanto na cidade Nova York a relação era de 1.045 para cada 100.000. Outros estudos têm mostrado que, em todas as sociedades e em todos os tempos, os adolescentes e jovens são os grupos sociais mais rebeldes e que mais infringem as leis sociais.

A questão da violência infanto-juvenil que se expressa na delinqüência, anteriormente relegada ao escopo da segurança pública, hoje invade o lar das famílias brasileiras através da mídia e do 'aprisionamento domiciliar' que a população vem vivenciando em resposta à insegurança do espaço comunitário. Alcançou os profissionais de saúde diretamente, ao fragilizar ainda mais os serviços públicos de atendimento e ao complexificar o atendimento cirúrgico. Aos pediatras, a situação de exacerbação dos 
conflitos sociais e, em particular, da delinqüência juvenil, trouxe à baila a noção de que seus pacientes não são apenas vítimas frágeis, mas, às vezes, cometem violências e brincam com armas poderosas de destruição. Novas fontes de informação e de reflexão tornaram-se necessárias para que se possa dar um atendimento adequado à situação da sociedade atual, em que, a maioria dos agravos à saúde se deve ao estilo de vida e muito menos a processos biológicos.

A conexão entre violência familiar e escolar também deve ser foco do setor saúde. Estudos têm identificado que adolescentes agredidos fisicamente em casa correm quatro vezes mais risco de serem diagnosticados como agressivos na escola. Profissionais de saúde e de educação precisam ter mais conhecimento que os habilitem a diagnosticar e a enfrentar os problemas trazidos pelos jovens, muitas vezes como um pedido de socorro.

\section{VIOLÊNCIA CONTRA A MULHER}

A violência contra a mulher para ser entendida precisa ser vista sob a perspectiva de gênero. Gênero diz respeito a relações de poder e à distinção entre características culturais atribuídas a cada um dos sexos e a suas peculiaridades biológicas. As características de gênero se fundam na hierarquia e na desigualdade de lugares sexuados. A violência de gênero distingue um tipo de dominação, de opressão e de crueldade estruturalmente construído nas relações entre homens e mulheres, reproduzido na cotidianidade e subjetivamente assumido, atravessando classes sociais, raças, etnias e faixas etárias.

A expressão violência de gênero deve muito de sua força ao movimento feminista que, junto com a politização da questão ambiental, constituem os dois mais importantes movimentos 
sociais do século XX. A partir da segunda metade desse século, sua estratégia de ação se centrou na desconstrução das seculares raízes culturais da inferioridade feminina e do patriarcalismo, nas denúncias das diversas formas de violência, nas tentativas de modificar as leis que mantinham a dominação masculina e na construção de novas bases de relação, protagonizadas por meio de mudanças de atitudes e de práticas nas relações interpessoais. A vitimização da mulher no espaço conjugal, por exemplo, foi um dos maiores alvos da atuação do movimento feminista que nos últimos cinqüenta anos vem buscando desnaturalizar os abusos, os maus-tratos e as expressões de opressão. Assim, problemas que, até então, permaneciam como segredos do âmbito privado - 'em briga de marido e mulher, ninguém mete a colher' - passaram a ter visibilidade social.

\section{Violência de gênero}

A violência de gênero, embora diga respeito a relações que envolvam homens e mulheres, incide principalmente sobre as pessoas do sexo feminino e constitui uma questão de saúde pública, além de ser uma violação explícita dos direitos humanos. Estima-se que esse problema cause mais mortes às mulheres de 15 a 44 anos que o câncer, a malária, os acidentes de trânsito e as guerras. Há uma estimativa brasileira de que pelo menos 35\% das queixas levadas pelas mulheres aos serviços de saúde estejam associadas a violências que sofrem, preferencialmente nas relações conjugais. Essas várias formas de opressão, de dominação e de crueldade incluem assassinatos, estupros, abusos físicos, sexuais e emocionais, prostituição forçada, mutilação genital, violência racial e outras. Os perpetradores costumam ser parceiros, familiares, conhecidos, estranhos ou agentes do Estado. Por ser 
a forma de violência de gênero mais freqüente na sociedade brasileira é dela que falarei a seguir.

Para conceituar a violência contra a mulher, fundamento-me aqui em uma definição da Sociedade Civil Bem-Estar Familiar no Brasil (Bemfam), que resume um conjunto de conceitos hoje vigentes: qualquer ato de violência baseada no gênero que resulta, ou que provavelmente resultará em dano físico, sexual, emocional ou sofrimento para as mulheres, incluindo ameaças, coerções ou privação arbitrária da liberdade, seja na vida pública ou privada.

A violência contra mulheres, em sua maioria, se exprime na esfera privada, embora, mostram as feministas, o âmbito privado seja político também. Por exemplo, manifesta-se no seio da família com a violação incestuosa, com as mutilações genitais, com o infanticídio, com a preferência pelo filho homem, com os casamentos forçados. Dentro do casamento, expressa-se na relação por meio do estupro conjugal, pelas pancadas, pelo controle psicológico, pelo proxenetismo, pelo crime de honra ou, às vezes, pelo assassinato da esposa.

No domínio público, a violência se manifesta pelo assédio sexual e moral no trabalho, pelas agressões sexuais, pelo estupro, pelo tráfico sexual, pelo uso da mulher na pornografia, pela escravidão e pelas esterilizações forçadas, dentre outras. Todas essas expressões, freqüentemente, são toleradas, silenciadas, desculpadas pela dependência das mulheres em relação aos homens ou por explicações psicologizantes inaceitáveis, tais como: os homens são incapazes de controlar seus instintos, os estupradores são doentes mentais, as mulheres gostam de homens agressivos.

A violência com desfecho fatal cometida contra as mulheres, em nível mundial, tem apresentado menor impacto quando comparada com a que vitimiza o sexo masculino. Em 2000, no mundo 
inteiro, 5 milhões de pessoas morreram por causas externas, e a mortalidade masculina foi duas vezes mais alta do que a feminina. Entretanto, em algumas regiões, as taxas de mortes femininas por suicídio e queimaduras são mais elevadas do que as mortes masculinas. $\mathrm{Na}$ China, por exemplo, as taxas de suicídio feminino chegam a ser duas vezes maiores do que as da população masculina.

A violência de gênero vitimiza a mulher por razões conjugais, sexuais ou culturais. Por exemplo, são conhecidos internacionalmente o assassinato de recém-nascidas na China e os crimes de honra em Marrocos e na Jordânia. Na sociedade brasileira, os homicídios provocados nas relações de gênero também ocorrem e são bastante comuns. No entanto, o que mais provoca sofrimento às mulheres são as lesões e traumas de que são vítimas nas interações cotidianas e naturalizadas.

Os termos utilizados para caracterizar as várias formas de violência contra a mulher no Brasil são os mesmos definidos no item "Natureza da violência" (capítulo 8), em que conceituo violência física, sexual, psicológica e negligências. Acrescento, a seguir, exemplos que ocorrem na realidade do país e devem ser vistos como as formas mais habituais.

\section{Violência sexual}

- Forçar relações sexuais quando a mulher está com alguma doença, colocando sua saúde em risco;

- Forçar relações sexuais, em geral;

- Estuprar e assediar sexualmente;

- Produzir gestos e atitudes obscenas nas relações com as mulheres;

- Discriminar a mulher por sua opção sexual. 


\section{Violência física}

- Agredir deixando marcas como hematomas, cortes, arranhões, manchas e fraturas;

- Quebrar seus objetos, utensílios e móveis;

- Rasgar suas roupas;

- Esconder ou rasgar seus pertences e documentos;

- Trancar a mulher em casa.

\section{Violência emocional e psicológica}

- Humilhar e ameaçar sobretudo diante de filhos e filhas;

- Impedir de trabalhar fora, de ter sua liberdade financeira e de sair;

- Deixar o cuidado e a responsabilidade do cuidado e da educação dos filhos e das filhas só para a mulher;

- Ameaçar de espancamento e de morte;

- Privar de afeto, de assistência e de cuidados quando a mulher está doente ou grávida.

Violência psicológica

- Ignorar e criticar por meio de ironias e piadas;

- Ofender e menosprezar o seu corpo;

- Insinuar que tem amante para demonstrar desprezo;

- Ofender a moral de sua família;

- Desrespeitar seu trabalho de cuidado com a família ou fora de casa;

- Criticar de forma depreciativa e permanentemente sua atuação como mãe e mulher;

- Usar linguagem ofensiva. 


\section{Violência social}

- Oferecer menor salário que ao homem, para o mesmo trabalho;

- Discriminar por atributos de gênero ou por aparência;

- Assediar sexualmente ou moralmente;

- Exigir atestado de laqueadura ou negativo de gravidez para emprego;

- Promover e explorar a prostituição e o turismo sexual de meninas e de adultas.

\section{VIOLÊNCIA CONTRA IDOSOS}

Segundo a Rede Internacional para a Prevenção dos MausTratos contra o Idoso, a violência contra esse grupo social é um ato (único ou repetido) ou omissão que lhe cause dano ou aflição e que se produz em qualquer relação na qual exista expectativa de confiança.

O conceito de maus-tratos usado pela citada Rede designa os abusos físicos, psicológicos, sexuais, os abandonos, as negligências, os abusos financeiros e as manifestações de autonegligências.

- Abuso físico, maus-tratos físicos ou violência física são expressões que se referem ao uso da força física para compelir os idosos a fazerem o que não desejam, para feri-los, provocarlhes dor, incapacidade ou morte.

- Abuso psicológico, violência psicológica ou maus-tratos psicológicos correspondem a agressões verbais ou gestuais com o objetivo de aterrorizar os idosos, humilhá-los, restringir sua liberdade ou isolá-los do convívio social.

- Abuso sexual, violência sexual são termos que se referem ao ato ou ao jogo sexual de caráter homo ou heterorelacional, 
utilizando pessoas idosas. Esses abusos visam a obter excitação, relação sexual ou práticas eróticas por meio de aliciamento, violência física ou ameaças.

- Abandono é uma forma de violência que se manifesta pela ausência ou deserção dos responsáveis governamentais, institucionais ou familiares de prestarem socorro a uma pessoa idosa que necessite de proteção.

- Negligência refere-se à recusa ou à omissão de cuidados devidos e necessários aos idosos, por parte dos responsáveis familiares ou institucionais. A negligência é uma das formas de violência contra os idosos mais presente no país. Ela se manifesta, freqüentemente, associada a outros abusos que geram lesões e traumas físicos, emocionais e sociais, em particular, para as que se encontram em situação de múltipla dependência ou incapacidade.

- Abuso financeiro e econômico consiste na exploração imprópria ou ilegal dos idosos ou ao uso não consentido por eles de seus recursos financeiros e patrimoniais. Esse tipo de violência ocorre, sobretudo, no âmbito familiar.

- Autonegligência diz respeito à conduta da pessoa idosa que ameaça sua própria saúde ou segurança, pela recusa de prover cuidados necessários a si mesma.

A partir da literatura internacional se sabe que a violência contra a população idosa é também problema mundial. Estudos de diferentes culturas e de cunho comparativo entre países têm demonstrado que pessoas de todos os status socioeconômicos, etnias e religiões são vulneráveis aos maus-tratos que ocorrem na velhice. Esses mesmos estudos mostram que uma pessoa de idade, vítima de violência, costuma sofrer simultaneamente vários tipos de maus-tratos, sendo os mais comuns, os de ordem 
física, psicológica, econômica e negligências. É de conhecimento de todos os pesquisadores que trabalham analisando arquivos de emergências hospitalares e de institutos médico-legais a existência de ações violentas contra idosos, como bases de lesões e traumas físicos, mentais e emocionais.

Os tipos de violência que a população idosa sofre coincidem com a violência social que a sociedade brasileira vivencia e produz nas suas relações e introjeta na sua cultura.

Os dados quantitativos retirados do Sistema de Informação de Mortalidade (SIM), do Ministério da Saúde mostram que óbitos de idosos por violências e acidentes ocupam o sexto lugar no seu perfil de morbi-mortalidade. No ano 2000, morreram 13.436 idosos por acidentes e vítimas de violências no país, significando, por dia, cerca de 37 óbitos, dos quais $8.884(66,12 \%)$ foram de homens e 4.552 (33,87\%) de mulheres.

Os acidentes de trânsito e as quedas são as principais causas de mortes violentas das pessoas desse grupo etário. Embora ambas subcausas poderiam ser interpretadas como algo 'não intencional' por parte de outrem, o aprofundamento dos estudos evidencia uma confluência de fatores apontando negligências e maus- tratos. Por exemplo, as quedas podem ser atribuídas a vários fatores: fragilidade física, uso de medicamentos que costumam provocar algum tipo de alteração no equilíbrio, na visão ou estão associadas à presença de enfermidades como osteoporose. Mas costumam também ser fruto da omissão e de negligências dos que deveriam prestar assistência nas casas, nas instituições e nas comunidades em que os idosos vivem.

No trânsito, os idosos passam por uma combinação de desvantagens: dificuldades de movimentos, próprias da idade, se somam à muita falta de respeito e mesmo a violências impingi- 
das por motoristas e a negligências do poder público. Uma das grandes queixas dos idosos se refere às longas esperas nos pontos de ônibus e aos arranques cometidos por motoristas que não os esperam se acomodar nos assentos. Estudos qualitativos têm mostrado que uma das formas de violência social e relacional da qual as pessoas mais velhas mais se ressentem é a forma como são tratadas nas travessias e nos transportes públicos, sendo objeto de humilhação e de discriminação.

Acidentes de trânsito, quedas e homicídios correspondem a quase $63 \%$ de todas as causas de mortes violentas de idosos no Brasil. Sozinhos, os homicídios correspondem a cerca de $10 \%$ do total dessas mortes. A ocorrência de vitimização por homicídios nessa faixa etária segue o padrão brasileiro dos outros grupos de idade, quando observado a partir da perspectiva de gênero: morrem mais homens que mulheres. A diferença é de 18,0/100.000 homens para 7,0/100.000 mulheres.

As taxas de suicídio entre os idosos são muito mais significativas do que a média para a população brasileira. Enquanto para o Brasil, em todas as idades, as taxas oscilam entre 3,5/100.000 e 4,0/100.000, em idosos elas correspondem a 7,5/100.000 e mostram leve tendência de crescimento. Nos países europeus, muitas investigações atribuem às elevadas taxas ao isolamento social, à desistência da vida quando, no caso dos casais, morre um dos cônjuges e, ainda, à emergência de enfermidades crônicas graves como o câncer, que as pessoas preferem não enfrentar. Como nos homicídios, os homens se suicidam mais que as mulheres, a diferença é de duas vezes mais para os primeiros.

No Brasil, as informações sobre doenças, lesões e traumas provocadas por causas violentas em idosos ainda são pouco consistentes, fato observado também na literatura internacional 
que ressalta uma subnotificação de $70 \%$ em todo o mundo. Apesar disso, a análise do Sistema de Informações Hospitalares (SIH) do SUS revela que no ano 2004 foram realizadas 108.169 internações de idosos por causas violentas e acidentes, sendo que $55,38 \%$ se deveram a quedas; $9,91 \%$ a acidentes de trânsito, sobretudo a atropelamentos; $2,86 \%$, a agressões e $0,65 \%$ a lesões autoprovocadas.

Ao contrário dos dados de mortalidade, as mulheres (58.416) utilizam mais os serviços por motivos de violências e acidentes do que os homens (49.753). O peso maior é das quedas, vindo, em segundo lugar, os acidentes de trânsito. A mortalidade dos velhos que se internam em conseqüência de acidentes e violências também é muito mais elevada $(5,42 / 100.000)$ do que na população em geral, (2,69/100.000). Autores nacionais e internacionais ressaltam a existência de uma razão de três quedas não fatais para cada queda fatal. E observam que a elevada relação entre mortes e lesões também costuma ser uma expressão de vários tipos concomitantes de maus-tratos por parte dos familiares ou dos cuidadores, dentro dos lares ou nas instituições de abrigo. Pelo menos um terço do grupo de idosos acima de 60 anos que vive em casa e a metade dos que vivem em instituições sofrem pelo menos uma queda anual. A fratura de colo de fêmur é a principal causa de hospitalização e metade dos idosos que sofrem esse tipo de lesão falece no período subseqüente de um ano. Grande parte dos que sobrevivem fica totalmente dependente dos cuidados de outras pessoas, o que representa altos custos financeiros e sociais.

Como já foi dito, as violências contra os idosos são muito mais intensas, disseminadas e presentes na sociedade brasileira que os dados epidemiológicos conseguem revelar. A violência 
estrutural, a violência institucional e a violência familiar, das quais os idosos são vítimas, ocorrem simultaneamente, pois assim como as crianças e os adolescentes, eles constituem um grupo muito vulnerável, sobretudo nos casos de múltiplas dependências e incapacidades. Dentre os problemas mais freqüentes ressalto:

\section{- Abusos financeiros e econômicos}

Como não há dados nacionais, usarei informações da Pesquisa do Instituto Brasileiro de Ciências Criminais, consolidando dados da Delegacia Especializada de Proteção ao Idoso de São Paulo. Essa investigação comprova que mais de 60\% das queixas desse grupo à polícia se referem a disputas dos familiares pela posse de seus bens ou por dificuldades financeiras das famílias em arcar com a sua manutenção. Os abusos geralmente são cometidos por familiares, em tentativas de forçar procurações que lhes dêem acesso a bens patrimoniais dos idosos; na realização de vendas de bens e imóveis sem o seu consentimento; por meio da expulsão deles do seu tradicional espaço físico e social do lar ou por seu confinamento em algum aposento mínimo em residências que, por direito, lhes pertencem, dentre outras formas de coação. As queixas de abuso econômico e financeiro se associam às várias formas de maus-tratos físicos e psicológicos que produzem lesões, traumas ou até a morte.

Mas os abusos econômicos e financeiros são muito mais universais. Eles ocorrem, direta ou indiretamente, também, nas relações com o próprio Estado, frustrando expectativa de direitos ou se omitindo na garantia dos mesmos. Acontecem, freqüentemente, nos trâmites para aposentadorias e pensões e, sobretudo, nas demoras de concessão ou correção de benefícios devidos, mesmo depois de 1994, quando 
a Lei 8.8.42 lhes passa a garantir prioridade de atendimento em órgãos públicos e privados. Nas delegacias de atenção e proteção ao idoso e nos núcleos de atendimento do Ministério Público, uma das solicitações mais reincidentes é que os agentes colaborem na solução de problemas com aposentadorias e pensões.

A violência estrutural reúne os aspectos resultantes da desigualdade social, da penúria provocada pela pobreza e pela miséria e a discriminação que se expressa de múltiplas formas. No Brasil, apenas 25\% dos idosos aposentados vivem com três salários mínimos ou mais. Portanto, a maioria deles é realmente pobre, morando com famílias pobres e miseráveis. Embora a questão social seja um problema muito mais amplo do que o que aflige os mais velhos, esses constituem um grupo muito vulnerável, por causa das limitações impostas pela idade, pelas injunções das histórias de perdas, problemas de saúde e de dependência.

A violência institucional no Brasil ocupa um capítulo muito especial. Ela é particularmente atualizada e reproduzida pelo Estado, por instituições públicas de prestação de serviços e por entidades públicas e privadas de longa permanência, no atendimento ao idoso.

No nível das instituições de prestação de serviços, as de saúde, assistência e previdência social (as que pela Constituição configuram o sistema de seguridade social) são campeãs de queixas e reclamações. Homens e mulheres pobres que não têm condições de optar por outros serviços, são os que mais sofrem. Muitos idosos verbalizam a idéia de que ser aposentado significa ser maltratado pelo sistema social de assistência pública. As longas filas, a comunicação confusa e impessoal, a falta de uma relação compreensiva com quem 
precisa de cuidados constituem expressões dessa violência.

Em grande parte das instituições (clínicas e asilos) de longa permanência, a violência institucional é freqüentemente naturalizada. Uma das formas mais cruéis da violência reproduzida nesses estabelecimentos se expressa na destituição do poder e da vontade e na despersonalização dos idosos que aí vivem. A crueldade da rotina de muitas delas costuma criar uma combinação de várias formas de violência: abandono familiar, negligência do Estado e abusos dos funcionários e donos. O caso da Clínica Santa Genoveva no Rio de Janeiro serve de exemplo dessa sinergia de maus-tratos. Nela morreram 156 pacientes em 1996, em conseqüência de problemas nutricionais e de falhas na assistência médica, do abandono dos familiares e da omissão do Estado. A situação que se dramatizou nessa mortalidade coletiva vinha se repetindo havia mais de dez anos.

\section{- Violência familiar}

Este tipo de violência contra idosos é um problema nacional e internacional. Pesquisas feitas em várias partes do mundo revelam que cerca de dois terços dos agressores são filhos e cônjuges. São particularmente relevantes os abusos e negligências que se perpetuam por choque de gerações, por problemas de espaço físico e por dificuldades financeiras que costumam se somar a um imaginário social que considera a velhice como 'decadência' e os idosos como 'descartáveis'. Todos os estudos existentes ressaltam a relevância de tocar nesse tema, pelo fato de que os cuidados com a pessoa idosa continuam a ser, na maioria das sociedades, responsabilidade das famílias. No Brasil, mais de $95 \%$ das pessoas acima de 60 anos estão morando com parentes ou vivem em suas próprias 
casas. E a violência familiar é enfatizada nos estudos brasileiros e internacionais como a mais freqüente forma de abuso contra os idosos.

Em geral os processos de agressão familiar têm as seguintes características: 1) o(a) idoso(a) vive na mesma casa que a vítima; 2) é um filho ou parente, dependente financeiramente do idoso de idade avançada; 3) o(a) idoso(a) é dependente da família para a manutenção e sobrevivência; 4) o(a) idoso(a) ou ou outra pessoa da família é um adicto a álcool ou a outras drogas; 5) o(a) idoso(a) tem ou manteve, ao longo da vida, vínculos afetivos frouxos com os familiares; 6) os familiares ou a pessoa idosa se isolam socialmente; 7) o(a) idoso(a) é ou foi muito agressivo(a) nas relações com seus familiares; 8) a pessoa idosa ou seus cuidadores têm história de violência intrafamiliar; 9) os cuidadores são ou foram vítimas de violência familiar, padecem de depressão ou de qualquer tipo de sofrimento mental ou psiquiátrico. Dentre todos os fatores de vulnerabilidade dos idosos, a grande maioria dos estudiosos ressalta a forte associação entre maustratos e dependência química. Pesquisas mostram que os agressores físicos e emocionais dos idosos costumam usar álcool ou outras drogas numa proporção três vezes mais elevada que os não abusadores.

Todas as investigações mostram também que, no interior da casa, as mulheres, proporcionalmente, são mais abusadas que os homens e, ao contrário, na rua, eles são as vítimas preferenciais. Em ambos os sexos, os idosos mais vulneráveis são os dependentes física ou mentalmente, sobretudo quando apresentam problemas de esquecimento, confusão mental, alterações no sono, incontinência, dificuldades de locomoção, necessitando de cuidados intensivos em suas atividades da vida diária. Como resul- 
tado dos abusos e maus-tratos, muitos idosos passam a sentir depressão, alienação, desordem pós-traumática, sentimentos de culpa e negação das ocorrências e situações que os vitimam e a viver em desesperança.

O Brasil possui hoje o Estatuto do Idoso, uma lei em que todos os direitos desses brasileiros são reconhecidos e reafirmados. Promulgado em 2003, uma de suas mais importantes contribuições é o reconhecimento do lugar, do papel e do protagonismo da pessoa idosa na construção da sociedade brasileira. 

Parte I I I

Modos de AtuaçÃo:

PESQUISA E INTERVENÇÃO 



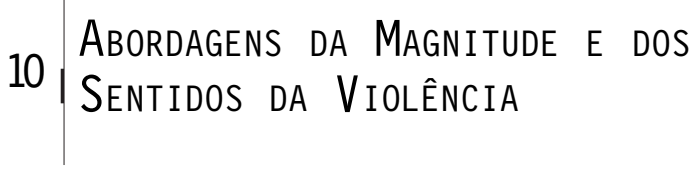

O Relatório da OMS propõe um modelo ecológico de explicação das raízes da violência (OMS, 2002). Em primeiro lugar, busca identificar os fatores biológicos que cada indivíduo apresenta em seu comportamento, concentrando-se nas características que aumentam a possibilidade da pessoa ser vítima ou perpetradora de violência.

Em segundo, são nomeados os fatores relacionais, evidenciando-se as interações sociais, nos âmbitos mais próximos dos companheiros, dos colegas, dos parceiros íntimos, dos membros da família, e sua influência na vitimização ou na perpetração da violência. No caso dos jovens, o documento reafirma a importância dos amigos como incentivadores de atividades delinqüenciais e criminosas.

Em terceiro, são colocados os fatores comunitários e sua influência na dinâmica da violência. Nesses contextos comunitários são nomeados os locais de trabalho, a escola e a vizinhança e, como problemas, os altos níveis de desemprego, a presença de tráfico de drogas e de armas e componentes de ordem relacional, como o isolamento social em que vivem determinadas famílias.

Em quarto, o modelo ecológico enfatiza os fatores sociais mais amplos que contextualizam os índices de violência. Dentre eles podem-se citar: normas culturais que justificam a violência como forma de resolver conflitos; atitudes que consideram a opção pelo 
suicídio como um direito de escolha individual; machismo e cultura adultocêntrica; normas que validam o uso abusivo da força pela polícia; normas que apóiam conflitos políticos.

No texto da OMS, discutem-se ainda as políticas econômicas e sociais, de educação, de saúde que contribuem para manter desigualdades, ou seja, para perpetuar as formas mais perversas de violência estrutural, e lembra que, dentro de uma perspectiva de desenvolvimento humano, são diferentes os elementos que influenciam a vitimização ou a perpetração de violência nas várias faixas etárias.

Assumindo a proposta ecológica, darei ênfase ao sentido dinâmico da produção da violência, cuja interpretação se adequa à teoria da causalidade complexa em que 'todas as coisas são causadas e causadoras' e em que se evidenciam a retroalimentação entre os fatores e a reflexividade dos fenômenos. Por isso, a tônica reflexiva e metodológica proposta é a articulação dos âmbitos biológico, subjetivo e social.

Desta forma, para se conseguir dimensionar e compreender o impacto da violência sobre a saúde, fazem-se imprescindíveis abordagens inter e transdisciplinares que incluam uma visão quantitativa e qualitativa do fenômeno. Não basta quantificar os mortos, os feridos, as vítimas e os agressores. Essas pessoas fazem parte de uma realidade histórica e cultural e possuem razões subjetivas, como extensamente já se mencionou anteriormente. Saber a magnitude do fenômeno, mas também os seus sentidos é pré-requisito para a formulação de programas de promoção e de prevenção propostos pelo setor saúde.

Do ponto de vista quantitativo é importante produzir conhecimento sobre: 
- a magnitude dos fenômenos em suas dimensões, traduzida em dados sobre morbidade e mortalidade;

- as diferenciações internas e as circunstâncias das fatalidades, dos traumas e das lesões que constituem as conseqüências da violência;

- os fatores que aumentam o risco de vitimização;

- os fatores que contribuem para a perpetração dos crimes e agressões;

- a especificação demográfica e ambiental dos eventos;

- as configurações de cunho local das expressões de violências que permitam a atuação por prioridades;

- a triangulação de dados epidemiológicos com informações históricas, culturais e subjetivas de cunho qualitativo.

Do ponto de vista qualitativo é fundamental desenvolver:

- a compreensão do momento histórico vivido pelo país e pelas regiões dentro do país, uma vez que a violência costuma ser um termômetro muito importante para medir as expressões dos conflitos, dos projetos, das crises e das expectativas sociais. Embora a violência seja um fenômeno permanente na história da humanidade, suas formas de manifestação são diferentes no tempo e no espaço;

- a compreensão da dinâmica dos contextos locais, culturais e das razões subjetivas com que as tipologias de violência se expressam;

- a articulação das informações compreensivas com dados quantitativos sobre os fenômenos, buscando responder a questões da prática;

- a integração da multiplicidade de atores cidadãos e institucionais na busca de formulação de políticas que afetem direta ou indiretamente a promoção de políticas e propostas e ação. 
Para tornar plausível a comparação entre países, a OMS, na Classificação Internacional das Doenças (CID), criou categorias para classificar os eventos violentos e os acidentes a serem notificados. Essa classificação se encontra nos códigos E-800 a E-999, na $9^{a}$ revisão da CID e nos V01 a Y98 na $10^{a}$ revisão. Cada vez que ocorre um evento violento no país, seu registro passa ou deveria passar, basicamente, pelas instituições e serviços mostrados na Figura 1.

Figura 1 - Fluxograma de notificação e esclarecimento de eventos violentos

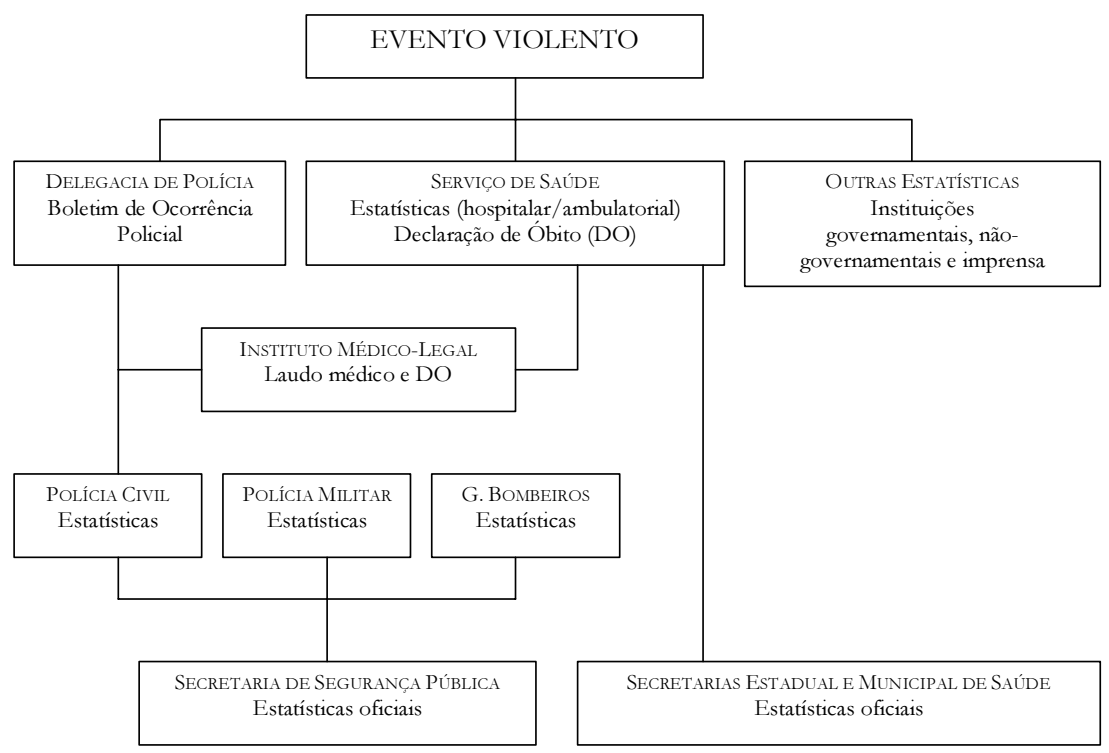

Fonte: Souza ( 2002: 259). 
Como se pode constatar, até chegar a se constituir em estatística oficial (é preciso não esquecer que muitos fatos não alcançam o conhecimento público), a informação de um evento violento passa por várias mãos e percorre diversas instituições. Está, pois, condicionada a problemas de idiossincrasias e finalidades dessas entidades, a questões ideológicas das pessoas que notificam e aos que procedem à notificação e às dificuldades ou facilidades tecnológicas e operacionais dos vários sistemas e fontes.

Tendo em vista que toda informação científica veiculada sobre o assunto não está isenta de problemas ideológicos e de dificuldades operacionais, pode-se dizer que os dados existentes no Ministério da Saúde e que são também repassados à OMS, para serem consolidados e comparados internacionalmente, não constituem uma verdade absoluta, mas são, acima de tudo, uma construção social.

Embora exista, por parte do Ministério e da maior parte das secretarias estaduais e municipais, uma busca insistente de melhorar a qualidade dos dados, do ponto de vista acadêmico, sua validade e confiabilidade são temas problemáticos. $\mathrm{Na}$ medida em que os pesquisadores operam no campo teórico e empírico, devem estar sempre atentos a como são geradas, coletadas, tratadas, organizadas, armazenadas, interpretadas e disseminadas as informações. Não basta, pois, ter um banco de dados e produzir análises estatísticas tecnicamente perfeitas a partir dele; é necessário perguntar-se sobre a qualidade dos processos que deram origem ao que está armazenado ou tecnicamente tratado.

O primeiro problema de fidedignidade surge no ato de apreensão e de compreensão do fenômeno da violência. Aí se cruzam elementos ideológicos com sistemáticas operacionais. Ideologicamente, a própria sociedade dá ênfase a determinados tipos de 
violência, ao passo que outros são deixados de lado ou são quase invisíveis, Por exemplo, os roubos, as lesões corporais, os homicídios são muito mais evidenciados do que as violências que ocorrem na família, que as discriminações raciais, contra deficientes físicos e mentais, de gênero e que os crimes de trânsito. A violência psicológica é muito difícil de ser dimensionada. Igualmente, no Brasil e no mundo, tabus e preconceitos explicam por que muitos suicídios e tentativas de cometê-los sejam intensamente subnotificados. E nas próprias unidades de saúde, os profissionais tendem a produzir informações apenas sobre as lesões e traumas dos quais tratam, sem se perguntarem pelo fato ou pela razão básica que os causou.

Por outro lado, é preciso ressaltar que, embora imperfeitos, o conjunto de fontes de informação e os esforços importantes que têm sido realizados para sua compatibilização são muito importantes para dar elementos no processo de produção de políticas de âmbito nacional. Eles apresentam indicadores de magnitude, de fatores de risco, de distinção de grupos mais vulneráveis e de tendências, ainda que imperfeitos. Um grande passo operacional deveria ser dado por todos os que atuam na área, no sentido de investir nos estudos operacionais que dão a dimensão e a compreensão das violências nos espaços locais, pois, as violências não são abstrações. É necessário conhecer com profundidade os contextos que as geram e sua dinâmica para que se possam estabelecer prioridades e agir intersetorialmente com apoio da sociedade civil, tendo em vista sua superação ou redução. 


\section{Elementos para Atuação do}

A busca de aprofundamento sobre o sentido do fenômeno da violência, malgrado o campo nebuloso de sua definição e conceituação, permite alguns consensos importantes que serão abordados de forma sucinta nos parágrafos a seguir.

A violência não se resume às delinqüências, e o homicídio é o ato mais hediondo nas relações sociais, pois ele efetiva o egocentrismo do ser humano: o aniquilamento do outro. Porém, além dos homicídios que nos apavoram, por se constituírem em sinônimo do que o imaginário social configura como 'violência', existem outras manifestações desse fenômeno que alimentam o acirramento das relações sociais. As formas culturalmente naturalizadas de agressões intrafamiliares, interpessoais, de discriminações raciais ou contra grupos específicos como homossexuais, de abusos e de dominação contra crianças, mulheres, idosos, deficientes físicos constituem um ambiente sociocultural adverso e, freqüentemente, marcado pela exclusão e lesões físicas e emocionais. Todas essas manifestações são potencializadoras da violência social difusa e ampla e se alimentam dela, como ressalta Domenach (1981) citado várias vezes neste livro.

É fato demonstrado pela realidade histórica que existem no Brasil regiões e cidades onde as taxas de violência são mais elevadas que em outras, sejam quais forem os tipos de manifestação do fenômeno. Portanto, a configuração espacial precisa ser incluída e articulada com especificidades históricas, sociais e cul- 
turais, visando a ações de promoção e de prevenção. A violência não é uma fatalidade nem uma abstração. Ela ocorre nas microrrelações e no contexto da vida. É fruto de observação e de pesquisas que as diferentes formas de violência se articulam criando uma expressão cultural naturalizada nas relações e nos comportamentos, atitudes e práticas.

Não tem consistência teórica qualquer proposta positivista que apresente planos mirabolantes para acabar com a violência num toque de mágica ou de autoritarismo. Ela precisa ser entendida e analisada como um fenômeno de expressão e parte constitutiva dos processos históricos complexos, nos quais é possível intervir.

As condições sociais e ambientais organizam o caráter eminentemente humano da violência. E por serem humanas, suas expressões incluem significado e intencionalidade.

Tem consistência a idéia de causalidade complexa da violência, com ênfase na embricação dos fatores históricos, contextuais, estruturais, culturais, conjunturais, interpessoais, mentais e biológicos. Sempre existirão elementos gerais e especificidades nas formas de apresentação e de reprodução desse fenômeno.

É muito mais profícuo, para efeitos de análise, trabalhar com a proposta de que existem violências em lugar de violência. Elas apresentam manifestações particulares e, geralmente, se encontram articuladas, umas potencializando as outras, como já foi dito.

É importante investir no conhecimento específico e empírico dos problemas, levando em conta: tempo, espaço, grupos atingidos, gravidade e representação, para compreender e para agir. Por ser um fenômeno humano-histórico, a violência está aí para 'dramatizar' causas, trazê-las à opinião pública e, incomodamente, propor e exigir mudanças. Porém, a compreensão de cada parte precisa ser articulada ao todo. 
No caso brasileiro, sobretudo nas regiões metropolitanas e nos grandes centros urbanos, a violência coletiva tende a vicejar persistente e vigorosamente na sua expressão instrumental, como recurso usado por muitas pessoas e grupos para conquistar mercados de bens e de poder. De um lado, ela manifesta o sentido de defasagem entre a oferta de condições e a escassez de espaços para um elevado percentual de indivíduos. De outro, ela canaliza demandas subjetivas de pessoas e grupos não contemplados na direção das novas formas de desenvolvimento. As expressões de violência devem ser entendidas, pois, como formas de vocalização dos sujeitos não reconhecidos, rejeitados e marcados pela exclusão e pela discriminação social.

A chamada violência tradicional, aquela que ressalta os conflitos comuns ou institucionais entre as pessoas e grupos, as frustrações das paixões nas relações de gênero, os furtos provocados pela fome, necessidade ou vício continuam a existir, têm seu espaço e respondem por grande parte das agressões e crimes. Ao mesmo tempo, essas expressões estão hoje subsumidas e potencializadas pelos gritos de um novo momento histórico, não ainda de todo claro e compreendido para ser enfrentado pelas forças políticas (novas forças políticas) renovadoras.

Não se pode compartilhar do imaginário da inevitabilidade e da falta de controle que freqüentemente é evidenciado pela opinião pública em relação ao fenômeno da violência. O presente e o futuro são criações humanas, com o barro das circunstâncias ao seu alcance.

A seguir, coloco algumas diretrizes de ação que se ancoram nos dois documentos oficiais sobre o impacto da violência e da saúde: o da OMS e do Ministério da Saúde: 
- Incentivo à promoção à adoção de comportamentos e de ambientes seguros e saudáveis, mobilizando a sociedade, em especial a mídia e os setores de educação, reforçando-se estratégias intersetoriais.

- Monitorização da ocorrência de acidentes e violências por meio do estabelecimento de ações padronizadas de vigilância epidemiológica que incluam: ampliação da abrangência dos sistemas de informação para que incorporem dados de atendimento dos pronto-socorros e dos ambulatórios; promoção da qualidade e padronização das informações.

- Sistematização, ampliação e consolidação do atendimento pré-hospitalar, prevendo-se a ampliação e implantação desse tipo serviço (quando for o caso), da padronização das normas e da criação de um sistema nacional de informações relativas a esses serviços.

- Assistência interdisciplinar e intersetorial às vítimas de violência buscando uma articulação do setor saúde com as áreas jurídicas e de segurança, desde os programas de Atenção Básica como o de Saúde da Família até os serviços ambulatoriais, emergenciais e hospitalares.

- Estruturação e consolidação do atendimento voltado para a recuperação e a reabilitação, hoje bastante escasso e salvo raras exceções, precário. A operacionalização dessa diretriz compreende a elaboração de normas e ao aparelhamento das unidades de saúde para o adequado atendimento aos pacientes;

- Capacitação dos profissionais do setor para habilitá-los, técnica e humanamente, para cuidarem das necessidades decorrentes da demanda que o problema das violências e dos acidentes está criando. Destacam-se como urgentes: treinamento para 
a melhoria da qualidade da informação; para o diagnóstico dos eventos; para as ações de prevenção e de vigilância epidemiológica, de atenção às vítimas (e não apenas às lesões) e de reabilitação psíquica e social.

- Apoio ao desenvolvimento de estudos e pesquisas interdisciplinares, estratégicas, operacionais e avaliativas.

Minha intenção, ao apresentar a trajetória do tema violências e acidentes na área da saúde, foi mostrar as dificuldades de sua legitimação, primeiro no âmbito social e, depois, nas instâncias que dão diretrizes para a atuação da área. A maioria das dificuldades decorre do fato de que o setor é profundamente marcado pela racionalidade biomédica. É difícil, para a comunidade dos profissionais de saúde e suas instituições, aceitar mudanças que incluem problemas complexos, cuja tônica são questões da vida social e não enfermidades. Freqüentemente tem-me ocorrido perguntar se morre mais quem morre de Aids ou de câncer do que quem morre no trânsito ou por homicídio.

Nessa pergunta não vai uma valorização da quantidade, embora o número de pessoas que vão a óbito por essas doenças seja muito menor do que os que são vitimados por violência. Também não está em jogo uma oposição entre os que passam por grandes sofrimentos com enfermidades degenerativas ou incapacitantes e as que sofrem violências. Mas, o que me aflige é não consideração do princípio ético segundo o qual, se todos morrem e todas as vidas são preciosas, o investimento nas várias áreas é igualmente importante, é crucial. No entanto, continuam sendo muito escassos os recursos (financeiros, de gestão, humanos e culturais), investidos na construção de meios para a compreensão da complexa problemática e para a busca de soluções adequadas em colaboração com outros âmbitos, como é o caso da segurança pública. 
Quis também valorizar o caminho percorrido pelo setor. A experiência mostra que, quando há ganhos e resultados positivos provenientes dos passos dados, encontramos mais ânimo e coragem para continuar no engajamento, na meta. Por isso, me empenhei em evidenciar os caminhos lentos e tortuosos pelos quais vai passando a inclusão do tema na pauta da área da saúde.

Há pelo menos três fatos que constituem símbolo dos resultados alcançados ao longo do processo. Um primeiro, é a construção coletiva e a promulgação do documento Política Nacional de Redução da Morbi-mortalidade por Acidentes e Violências (Brasil, 2001), pois, ao que parece, o país é pioneiro em adotá-lo. Um segundo é a elaboração de um Plano Nacional para aplicação da política, fundamentado em estudos e bases epidemiológicas. Igualmente, parece que o Brasil saiu na frente dessa ação planejada (Brasil, 2005a). E, em terceiro lugar, o documento denominado Impacto da Violência sobre a Saúde dos Brasileiros atende a uma recomendação da OMS de que cada país promova o seu diagnóstico para fundamentar suas ações (Brasil, 2005b). A iniciativa brasileira é também pioneira. Oxalá, todos os esforços empreendidos para criar parâmetros e diretrizes, frutos de tantas vozes simultâneas clamando por qualidade de vida e sob o influxo de tantas mortes evitáveis, sejam acompanhados de ações setoriais e intersetoriais condizentes e necessárias. O setor saúde, além da tradição de prevenção, tem a ótica do cuidado como ethos, no que se diferencia da práxis da segurança pública que visa a reprimir crimes e contravenções. Essa tradição do cuidado e da prevenção pode fazer toda a diferença! 


\section{REFERÊNCIAS}

AGUDELO, S. F. Violência, cidadania e saúde pública. In: BARRETO, M. L. et al. (Orgs.) Equidade e Saúde: contribuições da epidemiologia. Rio de Janeiro: Fiocruz, 1997.

ARENDT, H. Origens do Totalitarismo. São Paulo: Companhia das Letras, 1990.

ARENDT, H. Sobre a Violência. Rio de Janeiro: Relume Dumará, 1994.

ASSIS, S. G. Crianças e adolescentes violentados: passado, presente e perspectiva para o futuro. Cadernos de Saúde Pública, 10 (supl.1): 126134,1994.

ASSIS, S. G. Traçando Caminhos em uma Sociedade Violenta. Rio de Janeiro: Fiocruz, 1999.

BAKER, A. A. Granny battering. Modern Geriatrics, 5: 20-24, 1975.

BRASIL. Ministério da Saúde. Politica Nacional de Redução da Morbi-mortalidade por Acidentes e Violências. Portaria MS/GM n. 737, de 16/5/ 2001, publicada no DOU n. 96, seção 1e, de 18/5/2001. Brasilia: Ministério da Saúde, 2001.

BRASIL. Ministério da Saúde. Mortes por Armas de Fogo no Brasil (Org.: TOURINHO, M. F.). Brasília: Ministério da Saúde, 2004.

BRASIL. Ministério da Saúde. Plano Nacional de Redução de Acidentes e Violências. Brasília: Ministério da Saúde, 2005a.

BRASIL. Ministério da Saúde/Organização Pan-Americana da Saúde \& Claves/Fiocruz. Impacto da Violência na Saúde dos Brasileiros (Orgs.: SOUZA, E. R. \& MINAYO, M. C. S.). Brasília: Ministério da Saúde, 2005b. 
BRICEÑO-LEÓN, R. (Org.) Violencia, Sociedady Justicia en América Latina. Buenos Aires: Clacso, 2002.

BURSTON, G. R. Granny baterring. British Medical Journal, (3): 592, 1975.

CAMUS A. O Mito de Sísifo. Lisboa: Livros do Brasil, 1960.

CHESNAIS, J. C. Histoire de la Violence en Occident de 1800 à nos Jours. Paris: Robert Laffont Éditor, 1981.

DIAS, L. \& GAMBINI, R. Outros 500: uma conversa sobre a alma brasileira. São Paulo: Senac, 1999.

DOMENACH, J. M. La violencia. In: UNESCO (Org.) La Violenciay sus Causas. Paris: Unesco, 1981.

ELIAS, N. O Processo Civilizatório. Rio de Janeiro: Jorge Zahar, 1993.

ENGELS, F. Teoria da violência. In: Engels. São Paulo: Ática, 1981.

FLORES, R. Z. A biologia na violência. Ciência \& Saúde Coletiva, 7(1):197202, 2002.

FREUD, S. Por que a guerra? In: Obras Completas. v. 22: Rio de Janeiro: Imago, 1980.

KEMPE C.H. et al. The battered child syndrome. Journal of the American Medical Association, 181:17-24, 1962.

KLINEBERG, O. Las causas de la violencia desde uma perspectiva sociopsicológica. In: Unesco (Org.) Las Violenciasy sus Causas. Paris: Unesco, 1981.

LABORIT, H. Mecanismos biológicos y sociológicos de la agresividad. In: UNESCO (Org). Las Violenciasy sus Causas. Paris: Unesco, 1981.

MINAYO M. C. S. (Org.) Bibliografia Comentada da Produção Científica Brasileira sobre Violência e Saúde. Rio de Janeiro: Panorama/Ensp, 1990.

ORGANIZAÇÃO PAN-AMERICANA DE SAÚDE (OPAS). Violencia y Salud. Resolución n. XIX. Washington: Opas, 1994.

ORGANIZAÇÃO MUNDIAL DE SAÚDE (OMS). Salud Mundial. Genebra: OMS, 1993. 
RAINE, A. \& LIU, J. H. Biological predispositions to violence and their implications for biological treatment and prevention. Psychology, Crime and Law, 4: 107-125, 1998.

SOARES, L. E. Perspectiva de implantação de uma política nacional de segurança pública e de combate à violência. In: Câmara dos Deputados (Coordenação de Publicações). Violência Urbana e Segurança Pública. Brasília: Câmara dos Deputados, 2002.

SOARES, L. E. \& PIQUET CARNEIRO, L. Os quatro nomes da violência: um estudo sobre éticas populares e cultura política. In: SOARES, L. E. (Org.) Violência e Política no Rio de Janeiro. Rio de Janeiro: Relume-Dumará-Iser, 1997.

SOUZA, E. R. Processos, sistemas e métodos de informação em acidentes e violências no âmbito da saúde pública. In: MINAYO, M. C. S. \& DESLANDES, S. F. (Orgs.) Caminhos do Pensamento: epistemologia e método. Rio de Janeiro: Fiocruz, 2002.

VETHENCOURT, J. L. Psicologia de la violencia. Gaceta de la Asociación de Profesores de la Universidad de Venequela, 11: 5-10, 1990.

WIEVIORKA, M. O. O novo paradigma da violência. Tempo Social, 9(1): 5-42, 1997.

WIEVIORKA, M. O. La violence aujourd'hui. Ciência \& Saúde Coletiva, 11(2):310-315, 2006.

WOLFANG, M. E. \& FERRACUTI, F. The Subculture of Violence. Londres: Tavistock, 1967. 



\section{Sugestões DE LEITURAS}

Sobre a Violência (Rio de Janeiro: Editora Relume Dumará, 1994) e Origens do Totalitarismo (São Paulo: Companhia das Letras, 1990). De autoria de Hannah Arendt, são dois livros em que esta grande filósofa do século XX trata das raízes da violência nos seres humanos em relação; e nas sociedades. Trava um diálogo profícuo, profundo e polêmico com outros autores, sobretudo no campo da filosofia política, analisando que a violência não conforma a história e nem produz mudanças essenciais nos processos históricos. São muito interessantes as distinções que Arendt faz entre violência e poder.

A Violência Faz Mal à Saúde (2004). Livro organizado pelo Ministério da Saúde, para discutir e propor medidas de redução da violência contra crianças e adolescentes sob a luz do Estatuto da Criança e do Adolescente (ECA). Nele, experientes e renomados pesquisadores e profissionais debatem e apresentam dados a respeito de todas as formas freqüentes de maus-tratos e sobre o papel das políticas e dos serviços de saúde.

Violência sob o Olhar da Saúde: a infrapolítica da contemporaneidade brasileira. Organizado por M. C. S. Minayo e E. R. Souza. Rio de Janeiro: Fiocruz, 2003. Além da conceituação sociológica, filosófica e na área da saúde, este livro apresenta os resultados de uma revisão a respeito da produção brasileira sobre violência e saúde na década de 1990, sob os mais diferentes aspectos e sujeitos envolvidos. 
Impacto da Violência sobre a Saúde dos Brasileiros. Livro escrito pelos pesquisadores do Claves/Fiocruz, em colaboração com a Organização Pan-Americana de Saúde e com o Ministério da Saúde (2005). Realizando um estudo de série histórica a partir de dados do Sistema de Informação de Mortalidade (SIM) e do Sistema de Internações Hospitalares (SIH), os pesquisadores apresentam e problematizam informações sobre violência no trabalho, contra crianças e adolescentes, de gênero, de trânsito, homicídios, suicídios e apresentam propostas de atuação. O livro responde a uma demanda da OMS para que todos os países façam seus próprios relatórios, a exemplo do Relatório Mundial.

Relatório Mundial sobre Violência e Saúde. Documento oficial da OMS sobre o tema publicado e editado por Etienne Krug e colaboradores. O documento, que foi traduzido para o português no mesmo ano de sua divulgação (2002), apresenta, de uma vez por todas, a violência como um problema mundial de saúde pública e trata da violência juvenil, dos maus-tratos produzidos contra crianças e adolescentes no âmbito familiar, da violência perpetrada por parceiros íntimos, do abuso de idosos, da violência sexual, dos suicídios e da violência coletiva. O texto termina fazendo recomendações voltadas aos paísesmembros, no sentido de que se elaborem diagnósticos locais e planos de ação visando ao enfrentamento dos problemas. 

Formato: $12,5 \times 18 \mathrm{~cm}$

Tipologia: Letter Gothic e Garamond

Papel: Pólen Bold $70 \mathrm{~g} / \mathrm{m}^{2}$ (miolo)

Cartão Supremo $250 \mathrm{~g} / \mathrm{m}^{2}$ (capa)

CTP, reimpressão e acabamento: Imprinta Express Ltda.

Rio de Janeiro, junho de 2010

Não encontrando nossos títulos em livrarias, contactar a EDITORA FIOCRUZ:

Av. Brasil, 4036 - térreo - sala 112 - Manguinhos

21040-361 - Rio de Janeiro - RJ

Tel.: (21) 3882-9039 e 3882-9041

Telefax: (21) 3882-9006

www.fiocruz.br/editora | editora@fiocruz.br 

